\title{
Granite tors of Waldviertel (Lower Austria) as sites of geotourist interest
}

\section{Granitowe skałki regionu Waldviertel (Dolna Austria) jako obiekty geoturystyczne}

\author{
Aleksandra Michniewicz, Milena Różycka, Piotr Migoń \\ University of Wroctaw, Institute of Geography and Regional Development, \\ pl. Uniwersytecki 1, 50-137 Wroctaw, Poland \\ e-mails: aleksandra.michniewicz@uwr.edu.pl; milena.rozycka@uwr.edu.pl;piotr.migon@uwr.edu.pl
}
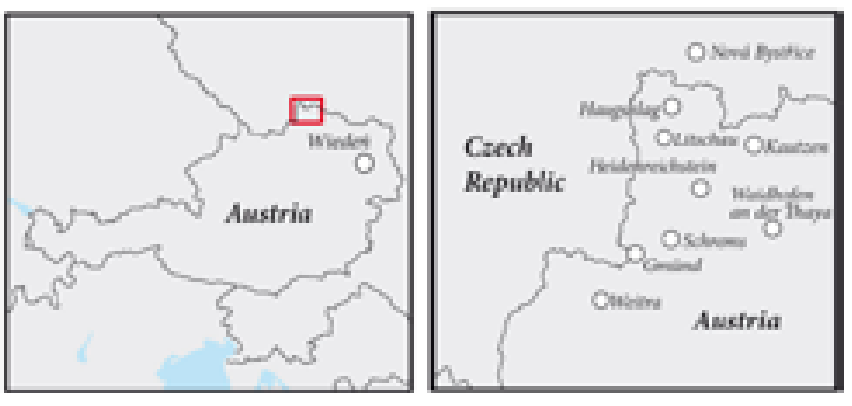

Abstract: Granites of the South Bohemian Pluton are among the main rocks in the region of Waldviertel in the northern part of Lower Austria. The overall topography is gently rolling, with higher elevations and medium-altitude mountainous relief present only in the south-western part. Tors are the most characteristic residual landforms and occupy different settings, from mountain tops to valley floors. They vary in shapes and dimensions, with castle koppies and boulder clusters being most common. Many tors host well-developed microforms such as weathering pits, karren, runnels, and flared slopes. Balanced rocks are among the highlights of the region. Because of good access residual granite landforms of Waldviertel are well suited to be developed as geosites and geotourist destinations, but there is clearly a deficit of explanation and interpretation. In this paper 15 representative tors are presented, tourist infrastructure is summarized, and a thematic one-day drive is proposed.

Key words: granite, granite geomorphology, geosites, Bohemian Massif

Treść: Granity plutonu poludniowoczeskiego należa do głównych skat wystepujacych $w$ regionie Waldviertel $w$ pótnocnej części kraju związkowego Dolna Austria. Region ten odznacza się lekko falista rzeźba, z większymi wysokościami i górzystym uksztattowaniem jedynie $w$ części poludniowo-zachodniej. Skatki stanowia najbardziej charakterystyczny element rzeźby denudacyjnej, zajmujac różna pozycję morfologiczna, od szczytów wzniesień po dna dolinne. Sa zróżnicowane pod względem kształtu i wymiarów, $z$ dominacja zamczysk skalnych i zgrupowań bloków (skałek rumowiskowych). Morfologie wielu z nich urozmaicaja mikroformy, takie jak kociołki wietrzeniowe, żłobki, rynny i nisze kloszowe. Szczególnie interesujacym elementem rzeźby regionu sa chybotki. Dobra dostepność sprawia, że rezydualne formy granitowe regionu sa odpowiednie do zagospodarowania jako geostanowiska i atrakcje geoturystyczne, choć uwage zwraca brak szerszego zaplecza edukacyjnego i interpretacyjnego. $W$ artykule przedstawiono 15 reprezentatywnych skatek granitowych, podsumowano zagospodarowanie turystyczne obszaru oraz zaproponowano przebieg jednodniowej tematycznej trasy samochodowej.

Stowa kluczowe: granit, geomorfologia granitowa, geostanowiska, Masyw Czeski

\section{Introduction}

Geoheritage sites are the principal resources of geotourism and may have different values associated with them and exploited by tourism industry. Whilst scientific values of geosites are often emphasized in regional assessments, as they directly translate into educational opportunities to tell geoscientific stories, scenic component of geosites is equally important, at least from the perspective of tourism industry. This refers particularly to landforms which may take intriguing, unusual, or even bizarre shapes and hence, would attract tourists whose interest in Earth history is minimal or non-existent. Then, an opportunity arises to provide more indepth explanation and interpretation. Thus, it is assumed that telling the story about rocks may be easier at natural rock outcrops rather than in quarries, particularly since in the former case the story would be more comprehensive, involving near-surface processes and landform evolution too. In addition, landforms are occasionally connected with folk tales and human history, providing links with cultural heritage.

The prime example of rock type that supports scenic landscapes, often promoted as tourist destinations, is granite. The aesthetic aspect of the landscape is often related to the presence of tors, i.e. residual landforms originally defined as "solid rock outcrops as big as a house rising abruptly from the smooth and gentle slopes of a rounded summit or broadly convex ridge" (Linton, 1955, p. 455).

Numerous examples of successful exploitation of granite heritage by tourism industry in general may be provided, from Europe and elsewhere. These are tors and crags of Fichtelgebirge in Germany, including the famous "rock city" of Luisenburg (Hundert Meisterwerke... 2012), the Pink Granite Coast in Brittany (France) (Lageat, 2013), or the upland of Dartmoor in south-west England with its multitude of tors (Campbell et al., 1998). Selected areas from outside Europe include granite geoparks of China such as Huangshan and Sanqingshan (Migoń, 2007; Cui et al., 2009), both also listed as UNESCO World Heritage properties, Matopos hills in Zimbabwe, and Joshua Tree National Park in the Mojave Desert of southern California. Singular localities are Wave Rock and Devil's Marbles, both in Australia (Twidale, 1968, 1982).

Compared with these worldwide known destinations, granite rock formations of Waldviertel in Lower Austria are of regional significance rather than enjoy wider recognition. Numerous tors and boulder fields have been often reported in the literature, but invariably local (see Huber, 1999 
for extensive bibliography). Nevertheless, even the literature survey alone indicates that the quantity and diversity of rock formations in Waldviertel, including minor features on rock surfaces, is exceptional, at least at the Central European scale. Hence, they are valuable assets for geotourism which so far is hardly supported by existing facilities and infrastructure.

Consequently, the aims of this contribution are threefold. First, more than a dozen of representative localities of granite residual landforms from Waldviertel are presented in a descriptive way, to show the value of granite geoheritage. Second, existing infrastructure is reviewed and evaluated. Third, a regional thematic geoheritage trail linking some key localities is proposed.

\section{Study area - location, geology and landscape}

The area considered in this paper is located in northern part of Austria, in the administrative state of Lower Austria (Niederösterreich), and in the region known as Waldviertel. However, the focus is not on the entire Waldviertel, but on its north-western part, along the border with the Czech Republic, between the towns of Weitra in the south-west and Kautzen in the north-east (Fig. 1). This area, approximately $45 \mathrm{~km}$ wide long and up to $20 \mathrm{~km}$ wide, is broadly coincident with the outcrop area of Eisgarner Granite, with minor representations of other granite variants. Further to the east, metamorphic rocks prevail or Weinsberger Granite occurs, which gives rise to residual rock landforms much less frequently. The main urban centre of the region, also the main tourist centre, is the town of Gmünd, located at the state border.

Geologically the area is part of the South Bohemian Batholith - the largest plutonic body in the Bohemian Massif, which in turn belongs to the Moldanubicum Unit of the Bohemian Massif (Koller, 1999). It is lithologically complex and consists of several distinctive granitoid units of different ages, testifying to multi-phase magmatic activity during the Variscan orogeny. Eisgarner Granite, which is the main tor-supporting lithology, is medium-grained, in places porphyritic, two-mica granite. Its emplacement took place between $333 \mathrm{Ma}$ and $315 \mathrm{Ma}$, during a later stage of the orogeny. Local finer or coarser variants may be even younger. Weinsberger Granite is older (350-335 Ma) and more deformed. Coarsegrained textures and large potassium feldspars are typical. Both variants show well-developed jointing, typically regular and orthogonal, but with variable joint spacing. Therefore, densely jointed compartments may occur side by side with very massive fragments, with visible discontinuities spaced as much as 3-4 m (horizontal) and more than $10 \mathrm{~m}$ (vertical) apart.

The later history of granite intrusions is poorly constrained, although it is likely that granites were unroofed in the latest Palaeozoic or early Mesozoic, suffered from protracted denudation and formed a low-relief terrain in the Cretaceous, when marine transgression took place in the marginal parts of the Bohemian Massif (Höck, 1999). Upper Cretaceous sediments laid down in a lacustrine environment occur in the town of Gmünd itself (Huber, 2003), a few kilometres from the nearest granite outcrops. However, the boundaries of the Cretaceous rock outcrop area are fault-controlled (Huber, 2003) and no recent exhumation of granite surfaces from beneath Cretaceous strata may be inferred.

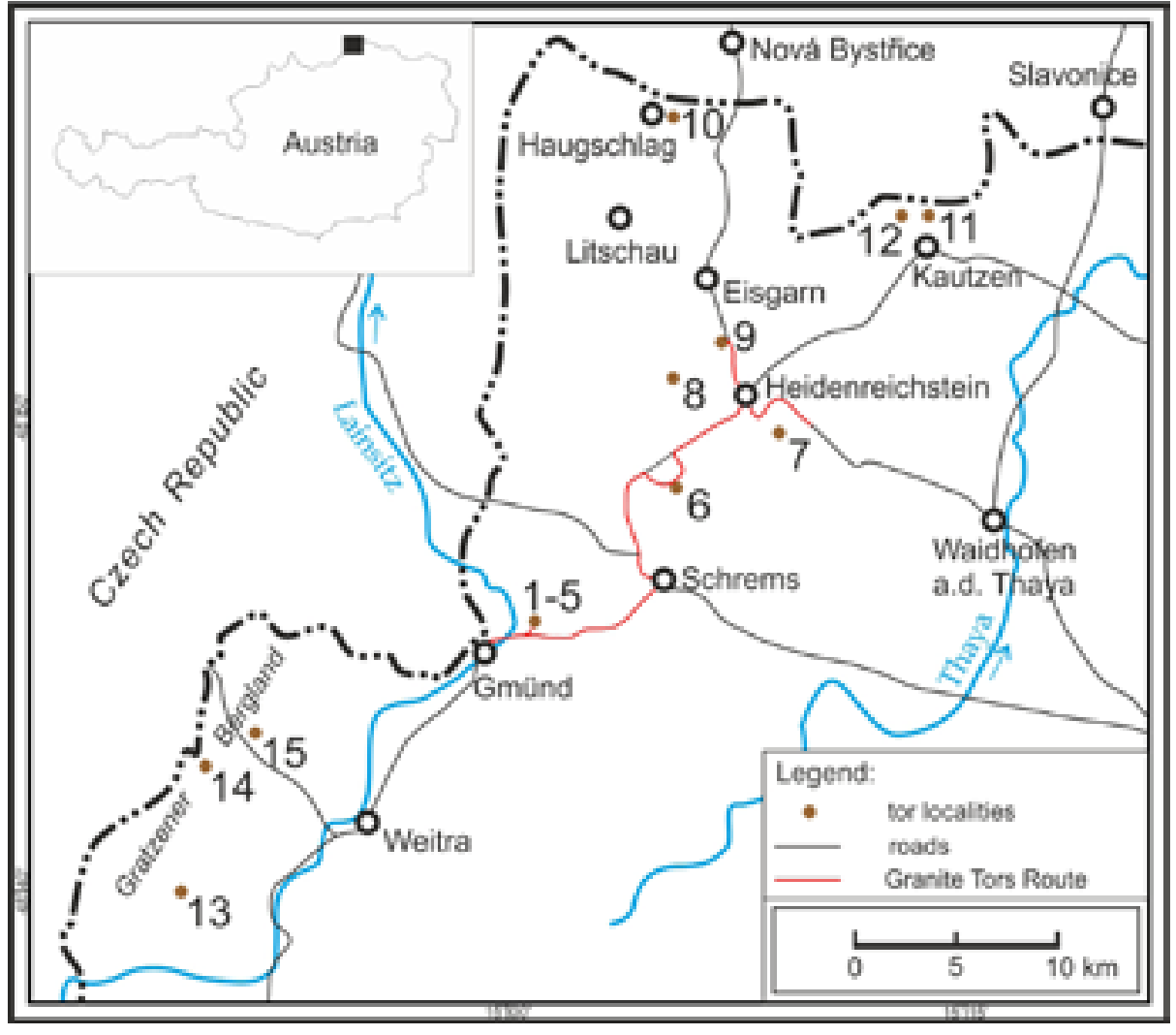

Fig. 1. Location of granite tors in north-western Waldviertel and proposal of a granite thematic drive. Tor localities: $1-5$ - Blockheide (Pilzfels, Christophorusstein, Wackelsteine, Teufelsbett, Koboldsteine), 6 - Wackelstein near Amaliendorf, 7 - Hängender Stein, 8 - Geyersteine, 9 - Gugelhupfstein, 10 - Hutstein, 11 - Hoher Stein, 12 - Teufelsstein, 13 - Mandlstein, 14 - Nebelstein, 15 - Dreilöcherstein - Lokalizacja skałek granitowych w północno-zachodniej części Waldviertel i propozycja tematycznej trasy samochodowej. 1-15-numeracja form skałkowych. 
The Cenozoic history of the area is unknown in details and typically presented using analogies to other, better researched terrains (Höck, 1999). The subdued topography of Waldviertel north of Gmünd (Fig. 2) is interpreted as a surface formed by selective deep weathering followed by stripping of weathering products, with alternating elevations and troughs. Tors are typically associated with the former, although they may occasionally rise from the floors of topographic lows too. Ridge altitudes are close to $600 \mathrm{~m}$ a.s.1., occasionally a little more (e.g. Hoher Stein, $666 \mathrm{~m}$ ), whereas valley bottoms are at $500 \mathrm{~m}$ a.s.1. By contrast, to the southwest of Gmünd the terrain rises to form a medium-altitude mountain terrain of Gratzener Bergland (Novohradské hory in the Czech Republic), with a number of peaks exceeding $1000 \mathrm{~m}$ a.s.l. A few localities from the north-eastern marginal part of this mountain terrain are considered here, including Nebelstein $(1017 \mathrm{~m})$, one of the highest in the region. Elevation differences between ridges and basin floors are up to 350-400 m.

\section{Geodiversity of granite terrains}

The South Bohemian Batholith, in the Austrian and adjacent Czech territory alike, is long known for its diversity of denudational landforms built of granites. Interpreted as an exposed weathering front - an etchplain (Czudek et al., 1964; Huber, 2003), it features a range of medium-size and minor landforms. The former include classic tors in a variety of shapes, rock cliffs across the slopes, pedestal rocks, including rocking stones, isolated boulders and boulder clusters, angular block fields and block streams (Votýpka, 1964; Věžník, 1982; Chábera, Huber, 1995, 1999; Huber, 1999). Rocking stones are of particular interest, not only as rare natural phenomena, but also as localities visited since the early days of tourism. The cluster of such balanced boulders (Wackelsteine in German) in Blockheide near Gmünd is among the highlights of the area, while the boulder Trkal in the Czech part was country-wide famous for its ability to move until recent minor displacement stabilized it (Věžník, 1982).

Tors and boulders host an astounding variety of minor features related to selective weathering of rock surfaces. Whilst abundant weathering pits (Votýpka, 1964; Věžník, 1982; Huber, 1999) may be considered typical for granite outcrops in the Bohemian Massif (Czudek et al., 1964), other features are indeed exceptional in terms of frequency of occurrence and clarity. These include particularly karren and flared slopes, but also polygonal cracking, pseudobedding, roofed and unroofed clefts and crevice caves (Chábera, Huber, 1995, 1996, 1998; Huber, Chábera, 1993, 1994).

\section{Tor localities}

From a large population of tors in Waldviertel a sample of 15 individual localities has been selected and is characterized in detail. These tors either best represent the diversity of granite residual rock formations in the region, or are

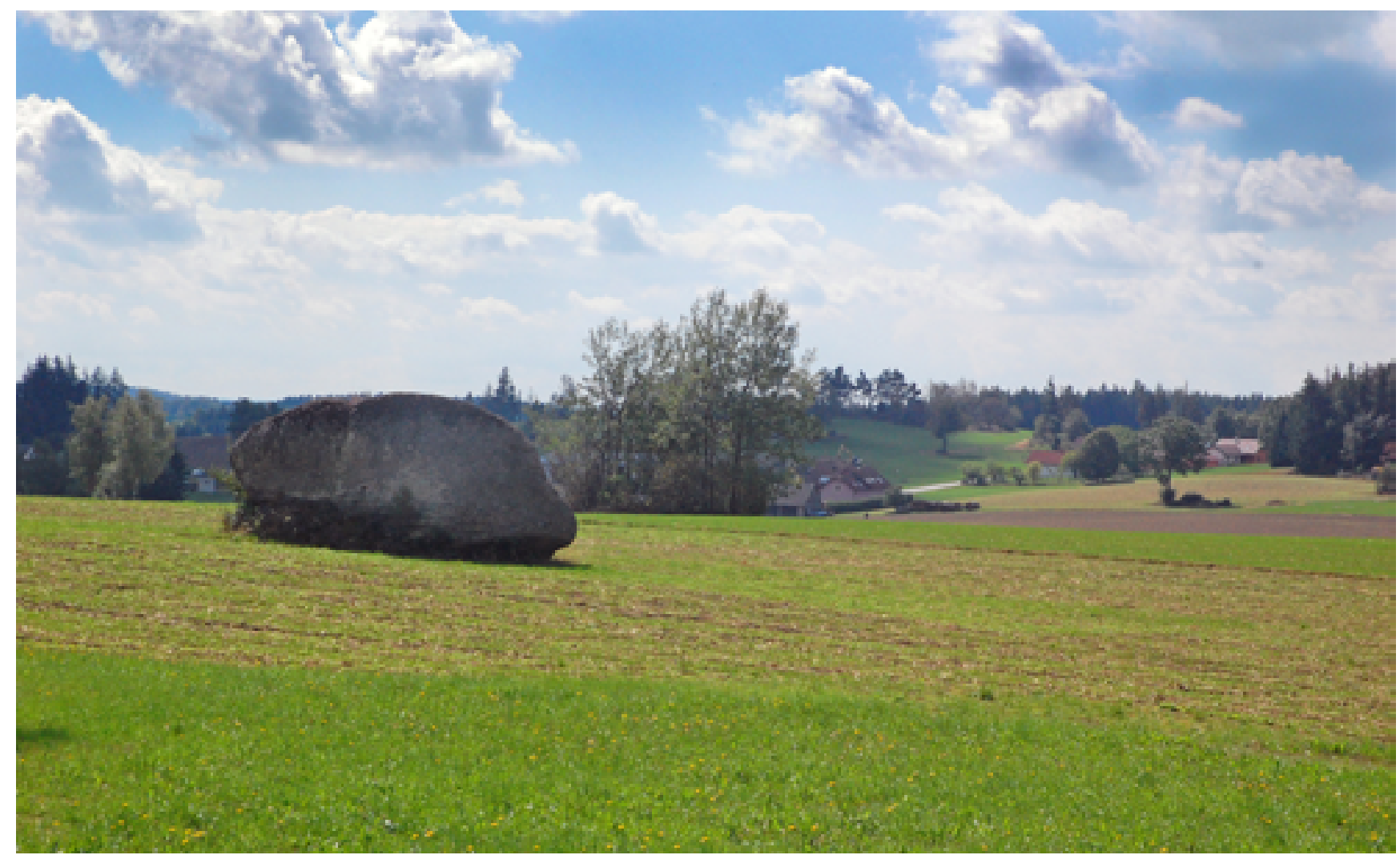

Fig. 2. Rolling countryside of northern Waldviertel, near Haugschlag. Note large granite boulders exposed due to erosion of weathering mantles, photo P. Migoń • Falisty krajobraz północnej części Waldviertel koło Haugschlag. Uwagę zwracają duże granitowe bloki odsłonięte wskutek usunięcia pokrywy zwietrzelinowej, fot. P. Migoń 
popular tourist/sightseeing destinations, or preferably both. Their presentation is divided into four sections, focused on specific parts of Waldviertel.

\section{Blockheide}

Blockheide Nature Park is a protected area to the east of the town of Gmünd, which is famous for the abundance of granitic tors and boulders and hence, frequently visited and promoted as one of main tourist attractions of the region. The overall topography is rolling, with wide troughs alternating with gentle swells. Altitudes do not exceed $600 \mathrm{~m}$ a.s.l. All tors and boulders in this area are built of Eisgarner Granite. Among numerous rock formations in Blockheide the following five are most spectacular.

Pilzstein. Pilzstein is one of the symbols of Blockheide. Reaching the height of $4.5 \mathrm{~m}$ and being approximately $6.5 \mathrm{~m}$ long and wide alike, the tor consists of two spherically shaped, massive blocks superimposed upon a rather narrow and thin stem (Fig. 3). The larger cap block (c. $40 \mathrm{~m}^{2}, 2 \mathrm{~m}$ thick) rests on the smaller one. The stem is built of densely fractured granite, with several sub-horizontal joint surfaces dipping at low angle. Cavernous weathering occurs along the joints. The depth of overhang beneath the cap varies and reaches more than $2 \mathrm{~m}$ on the western side. Pilzstein, as most of the tors in Blockheide, is located next to a marked trail and is frequently visited. However, no other information board than the simple plaque with the tor name exists in the vicinity of the site. Pilzstein has been described in the literature (Chábera, Huber, 1995; Huber, 1999) as a prime example of 'mushroom' rocks. Next to Pilzstein a large number of boulders and/or hemispherical granite outcrops occurs. Some of them show well developed flared slopes, including tiered ones.

Christophorusstein. Christophorusstein (Fig. 4) is perhaps the largest singular tor in Blockheide, located in its southern part, in a slope setting. It is $22 \mathrm{~m}$ long and $7 \mathrm{~m}$ high, and - being an example of a castle koppie - consists of several compartments separated by deep clefts developed as a result of widening of vertical joints striking SW-NE. A notable feature is fairly regular pseudobedding, with the thickness of particular slabs exceeding $1 \mathrm{~m}$. Morphology of the upper surface of the tor is diversified by minor features, including ten weathering pits of various dimensions (Fig. 5). The largest one is $1.8 \mathrm{~m}$ long, $1 \mathrm{~m}$ wide and $0.3 \mathrm{~m}$ deep. Christophorusstein is easily reached by a marked trail and clearly visible despite forest location. A stone-made board with the name of the tor has been placed nearby, whereas an information panel next to the tor presents the legend of Christophorus Rock and explains the name. It is also a part of the thematic GRANITkulTOUR trail which connects more than ten localities in SE section of Blockheide. A small plaque attached to the rock form gives information of its protected status.

Wackelsteine. Among the highlights of Blockheide are several perched boulders resting on rock platforms, which show (or showed) ability to move and are called Wackelsteine (Chábera, Huber, 1995). The largest balanced rock, located in the southern part of the area, close to Christophorusstein, is $9.3 \mathrm{~m}$ long and reaches $2.5 \mathrm{~m}$ high (Fig. 6).

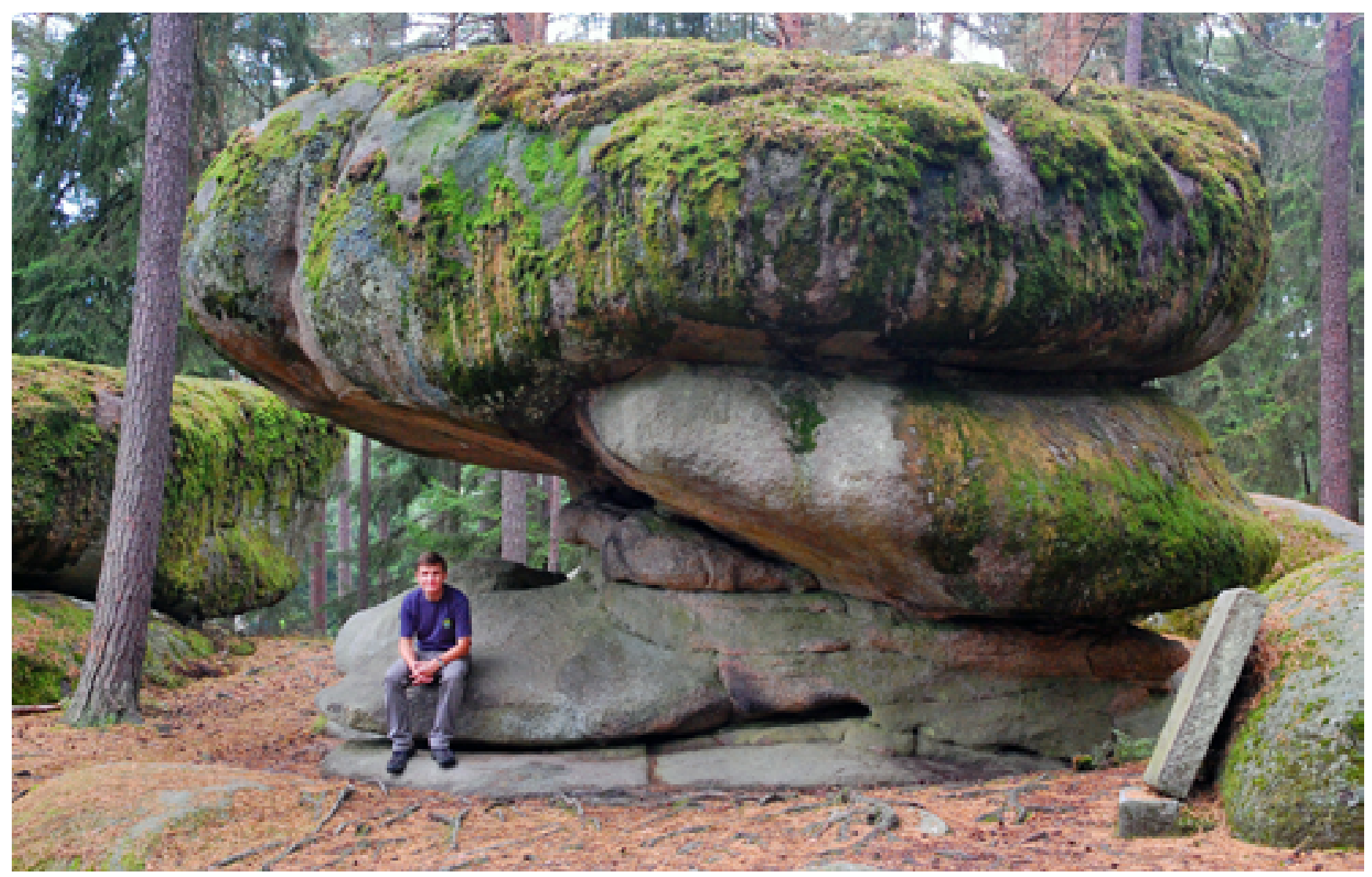

Fig. 3. Pilzstein, with a large overhang on the western side, photo M. Różycka • Pilzstein ze znacznych rozmiarów przewieszką od strony zachodniej, fot. M. Różycka 


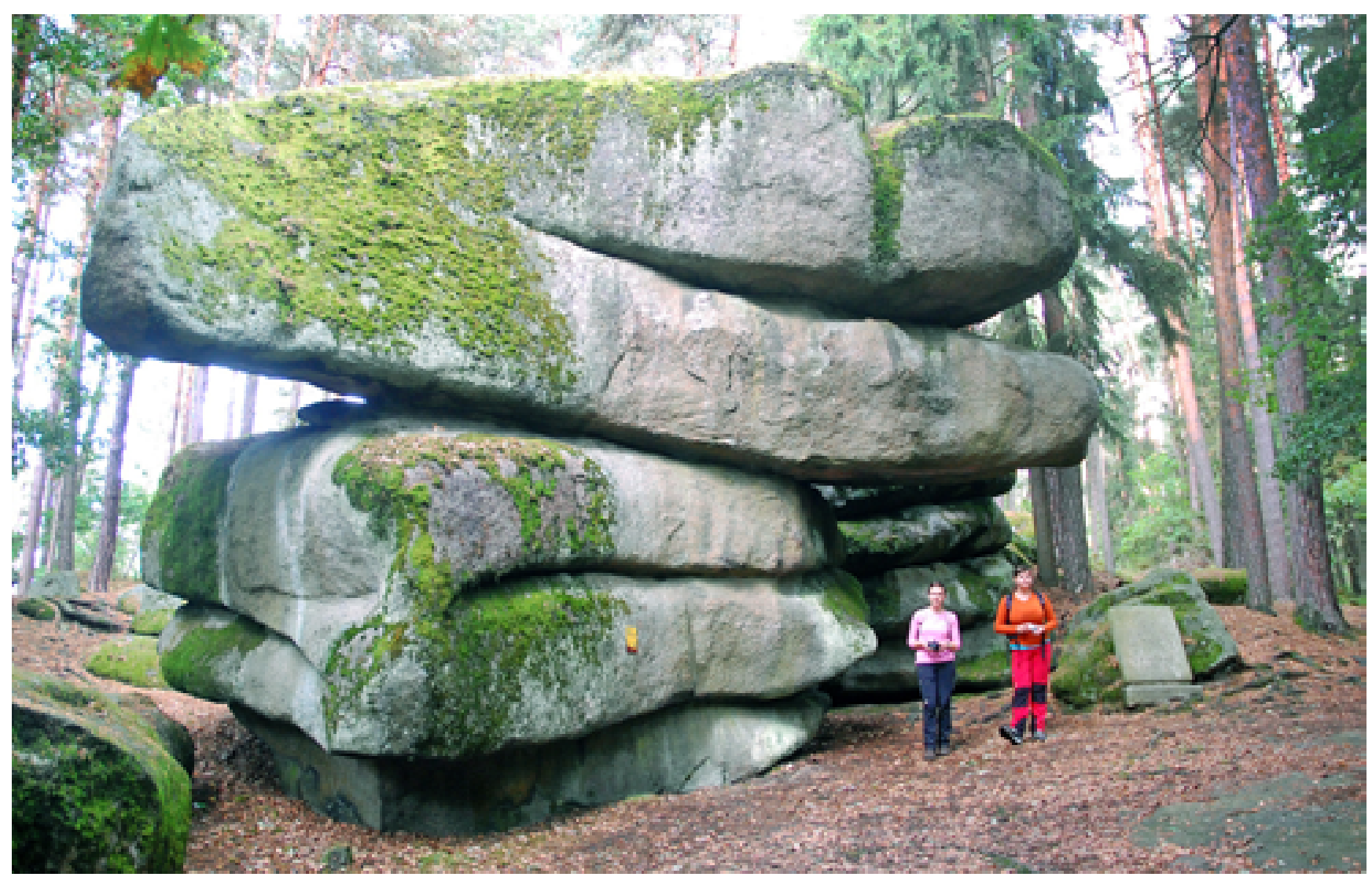

Fig. 4. The shape of Christophorusstein is related to the presence of thick slabs of massive granite, photo P. Migoń • Kształt Christophorusstein nawiązuje do obecności grubych płyt masywnego granitu, fot. P. Migoń

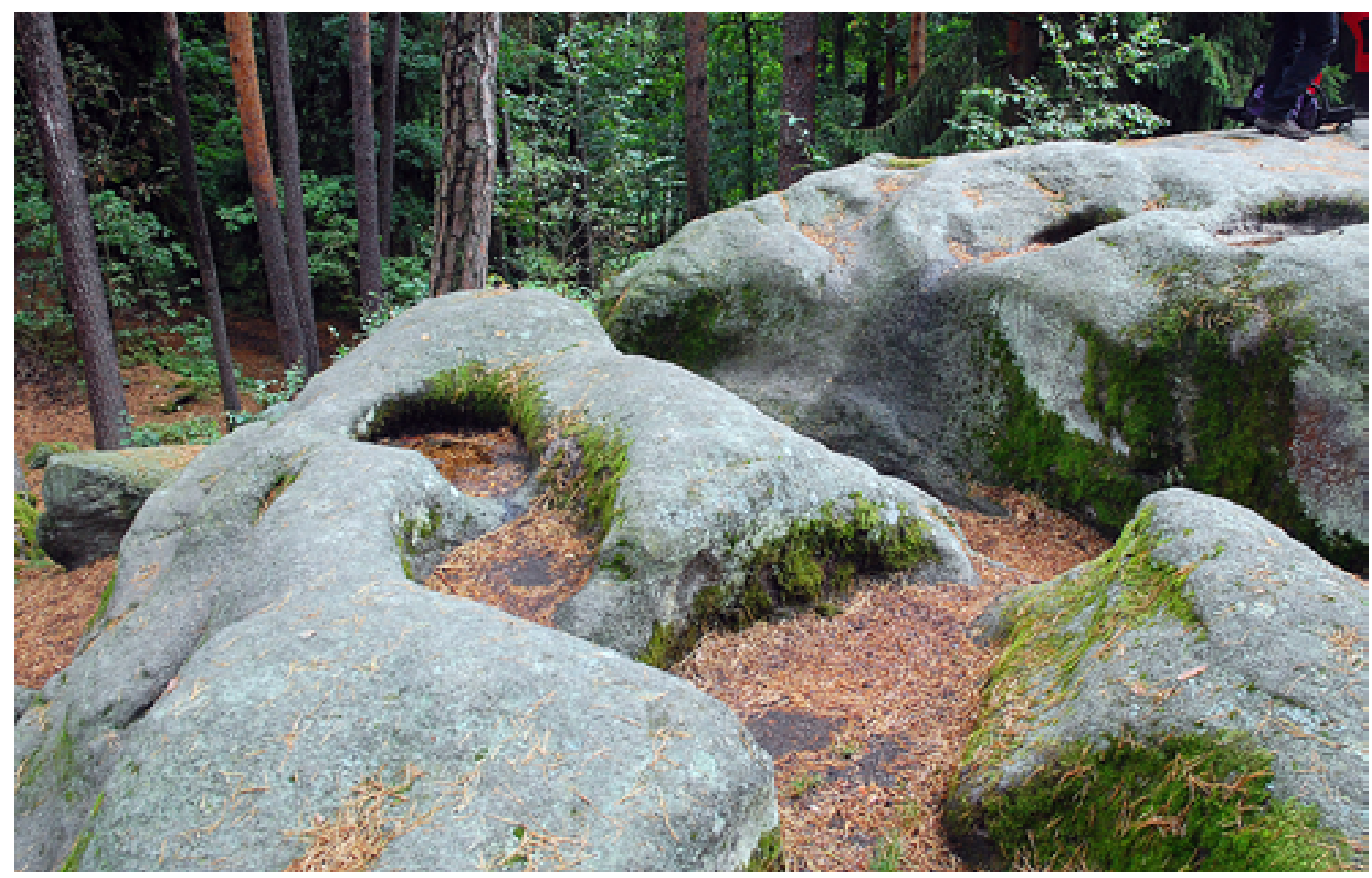

Fig. 5. Weathering pits on the upper surface of Christophorusstein, photo P. Migoń - Kociołki wietrzeniowe na powierzchni szczytowej skałki Christophorusstein, fot. P. Migoń 


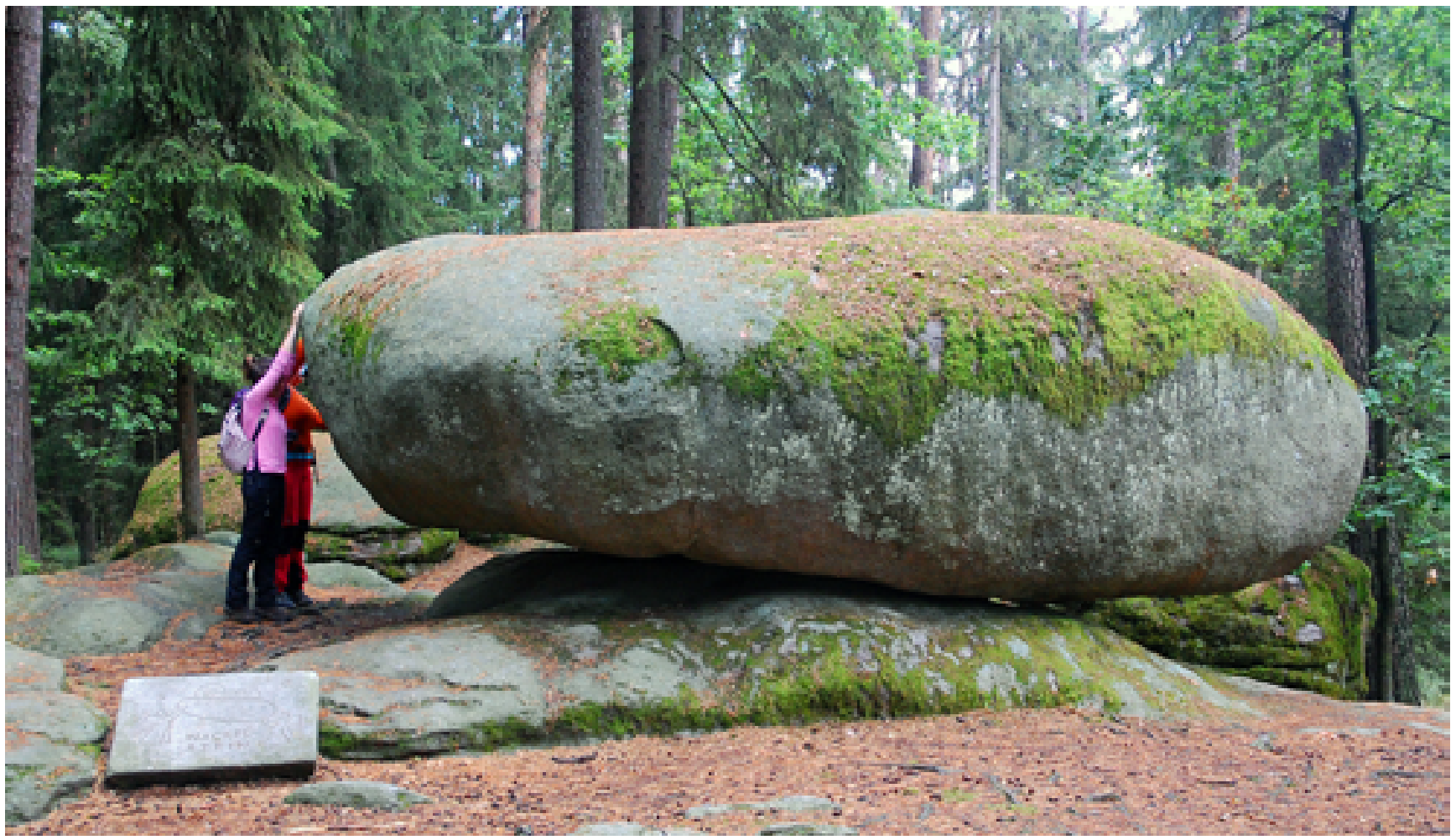

Fig. 6. Wackelstein II is the best example of balanced rock in Blockheide, photo P. Migoń • Wackelstein II jest najlepszym przykładem chybotka w Blockheide, fot. P. Migoń.

A large elongated rounded boulder lies on an upward-convex platform, slightly protruding from the ground. The length of the pedestal is $7.3 \mathrm{~m}$. The upper boulder is massive and bare, only partially covered by mosses in the top part. In contrast to the nearby Christophorusstein no specific microrelief typifies its surface, which is probably related to boulder instability, unfavourable for localized higher efficacy of weathering. The site is easily accessible and well signposted, located next to the GRANITkulTOUR trail. The name of the rock group has been carved in a stone-made board placed near the site, but otherwise no further explanation or interpretation is offered. Two other balanced rocks, both of smaller dimensions, are present in the eastern part of the area and signposted.

Teufelsbett and Teufelsbrotlaib. Teufelsbett and Teufelsbrotlaib are excellent examples of very large, monolithic granite boulders which dot the rolling countryside around Gmünd. The larger among the two, an elongated Teufelsbett reaches height of $4.2 \mathrm{~m}$ and length of $10.6 \mathrm{~m}$ (Fig. 7). Very few joints present within the boulder divide the outcrop into three spherically-shaped parts resembling a bed, a pillow and a duvet. There is no evidence of mechanical disintegration in the vicinity of the boulder, nor are minor forms related to biochemical weathering such as karren and pits visible on the rock surface. The adjacent Teufelsbrotlaib is slightly smaller, $4.2 \mathrm{~m}$ high and $6.2 \mathrm{~m}$ long, and more ball-shaped. On the curved rock surfaces exfoliation sheets are present. Both boulders are located at the intersection of walking trails running around Blockheide, and separated from each other by c. $20 \mathrm{~m}$. They are very well exposed and easily accessible. The rock-cut boards with the name of an object have been placed next to them, as well as are small plaques indicating their status as protected nature monuments.

Koboldsteine. Koboldsteine are located in the north-western section of Blockheide, c. 200 m north from the observation tower. The name was given to a series of well-rounded boulders and monoliths along the crest of a local N-S stretching terrain convexity, across the distance of approximately $50 \mathrm{~m}$. Individual compartments reach up to $5 \mathrm{~m}$ high and are separated by vertical fractures of $\mathrm{W}-\mathrm{E}$ extension which in places turn into open fissures up to $2 \mathrm{~m}$ wide. The entire rock formation is divided into three groups of closely-spaced boulders, whereas in between them bedrock outcrops are missing. On top of one such a boulder a balanced rock $(2 \mathrm{~m}$ high) is present. The evidence of block sliding can also be observed, as well as two generations of flared slopes near the base of some boulders. Koboldsteine are easily accessible and well-exposed despite surrounding trees, marked by a board indicating the name. Yellow and pink-marked trails connect them with other sites of interest in the vicinity.

\section{Tors in northern Waldviertel}

Wackelstein near Amaliendorf. Approximately 4 km north of the town of Schrems and $1.5 \mathrm{~km}$ west from Amaliendorf, a cluster of large monolithic granite blocks amidst an open pine forest is present. The most popular among them is Wackelstein which is yet another example of balanced rocks in Waldviertel (Chábera, Huber, 1995). The perched boulder is $3 \mathrm{~m}$ high and $5 \mathrm{~m}$ long, and rests on a flat pedestal. Its bottom part is convex downward which results in its instability. 


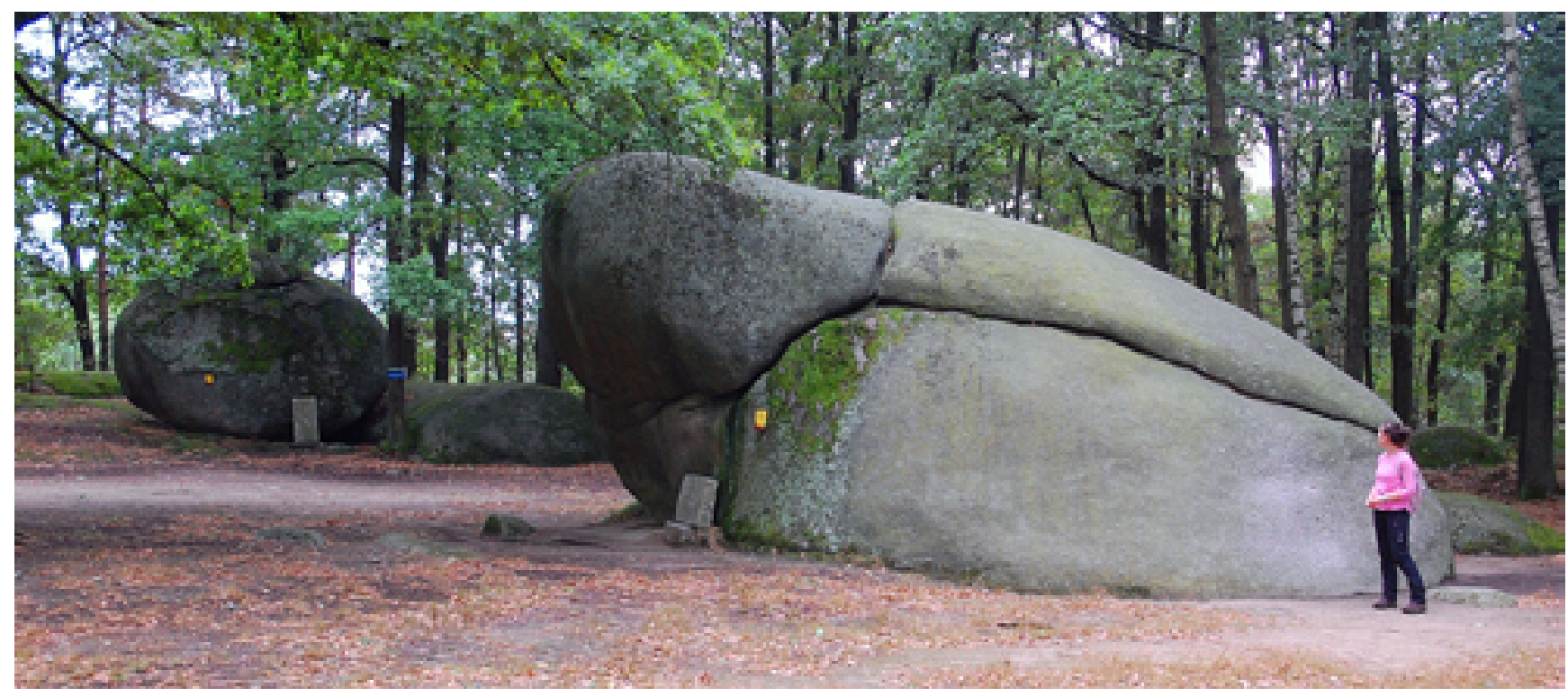

Fig. 7. Teufelsbett (right) and Teufelsbrotlaib (left, in the background), photo P. Migoń • Teufelsbett (po prawej) and Teufelsbrotlaib (w tle po lewej), fot. P. Migoń

The upper part of the boulder is hemispherical and has smooth outer surface, except for the series of small notches hollowed in one side of the block. In the vicinity of Wackelstein other interesting boulders are located. Next to the balanced rock large, massive compartments with well-developed weathering pits, some as long as $1.5 \mathrm{~m}$, occur. Furthermore, lower sides of certain blocks show classic basal concavities, known as flared slopes and indicative of shallow subsurface weathering, some up to $10 \mathrm{~m}$ long and $0.5 \mathrm{~m}$ high. A rare phenomenon, with a few equivalents elsewhere, is a pair of flared slopes on two adjacent boulders facing each other and separated by an open cleft (Fig. 8). In addition, rock outcrops near Amaliendorf show signs of quarrying, both in the form of stone quarries as well as split boulders.

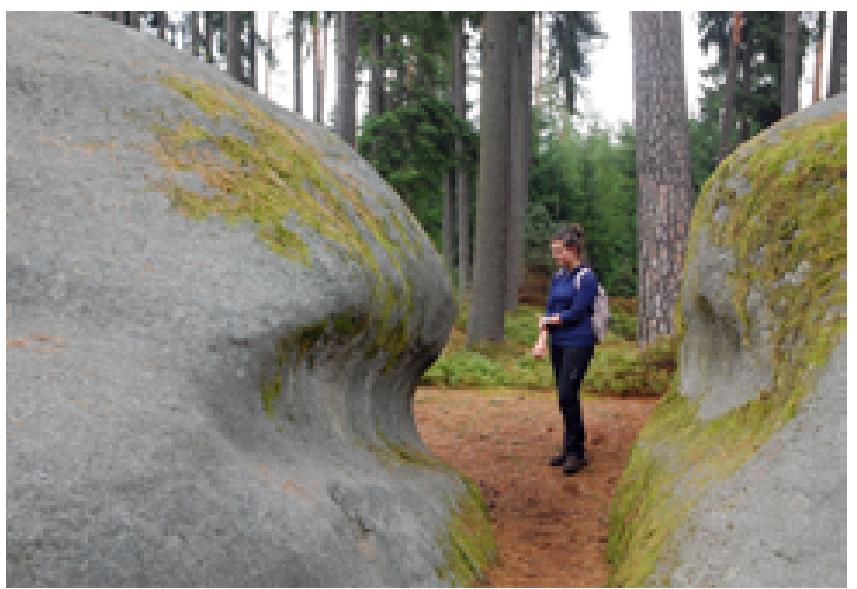

Fig. 8. A pair of flared slopes along a widened joint-controlled defile between two granite outcrops, near Amaliendorf, photo P. Migoń - Para nisz kloszowych wykształconych wzdłuż poszerzonej szczeliny pomiędzy dwiema wychodniami granitu, w pobliżu Amaliendorf, fot. P. Migoń
Wackelstein is a nature monument, although it is not marked on all tourist maps. The easiest access to the site is from Amaliendorf, from where a forest road and a marked trail lead to the site. On the edge of the forest, where is space to park a car, an information board has been erected.

Hängender Stein. The tor group is located c. $1.5 \mathrm{~km}$ southeast from the centre of Heidenreichstein, at the altitude of $606 \mathrm{~m}$ a.sl. Morphologically, Hängender Stein is a bipartite tor, with the tabular shape influenced by prominent, low angle dipping joints. The northern part is $7.2 \mathrm{~m}$ long, $2.5 \mathrm{~m}$ high and elongated in N35E direction, along parallel vertical joints. One weathering pit has evolved on the surface of this part. Joints perpendicular to those mentioned above (N335W) determine the outline of the southern section of the tor. This part is elongated too and longer than the northern one, reaching $8.8 \mathrm{~m}$. The top part is made of a large 'hanging' block, $5 \mathrm{~m}$ long and $3 \mathrm{~m}$ high, narrowing toward the base. Its upper surface is diversified by more than 20 linear furrows of variable length (0.3-4 m) and depth (1-25 cm) (Fig. 9), which either dissect the edge of the tor (karren) or form dendritic patterns on its upper surface (runnels) (Huber, Chábera, 1993).

The tor is situated in the Gemeindewald, whose area is easily accessible through a network of marked trails. The tor is best reached from a parking near the Heidenreichstein Johanessiedlung road and the walk takes approximately 15 minutes. Tourist facilities next to the site include benches and an information board. It is the only site among those presented in this paper where the origin of granite tors in two stages (deep weathering followed by selective erosion) is explained and graphically presented. Gemeindewald is a local protected area.

Geyersteine. The tor is located $3.3 \mathrm{~km}$ west from Heidenreichstein and $1.5 \mathrm{~km}$ to the south-west from the village of Altmanns, at the altitude of $545 \mathrm{~m}$ a.s.l. The outcrop, $7 \mathrm{~m}$ high in total, rises from the steep left side of a valley formed by the tributary of the Braunaubach stream. 


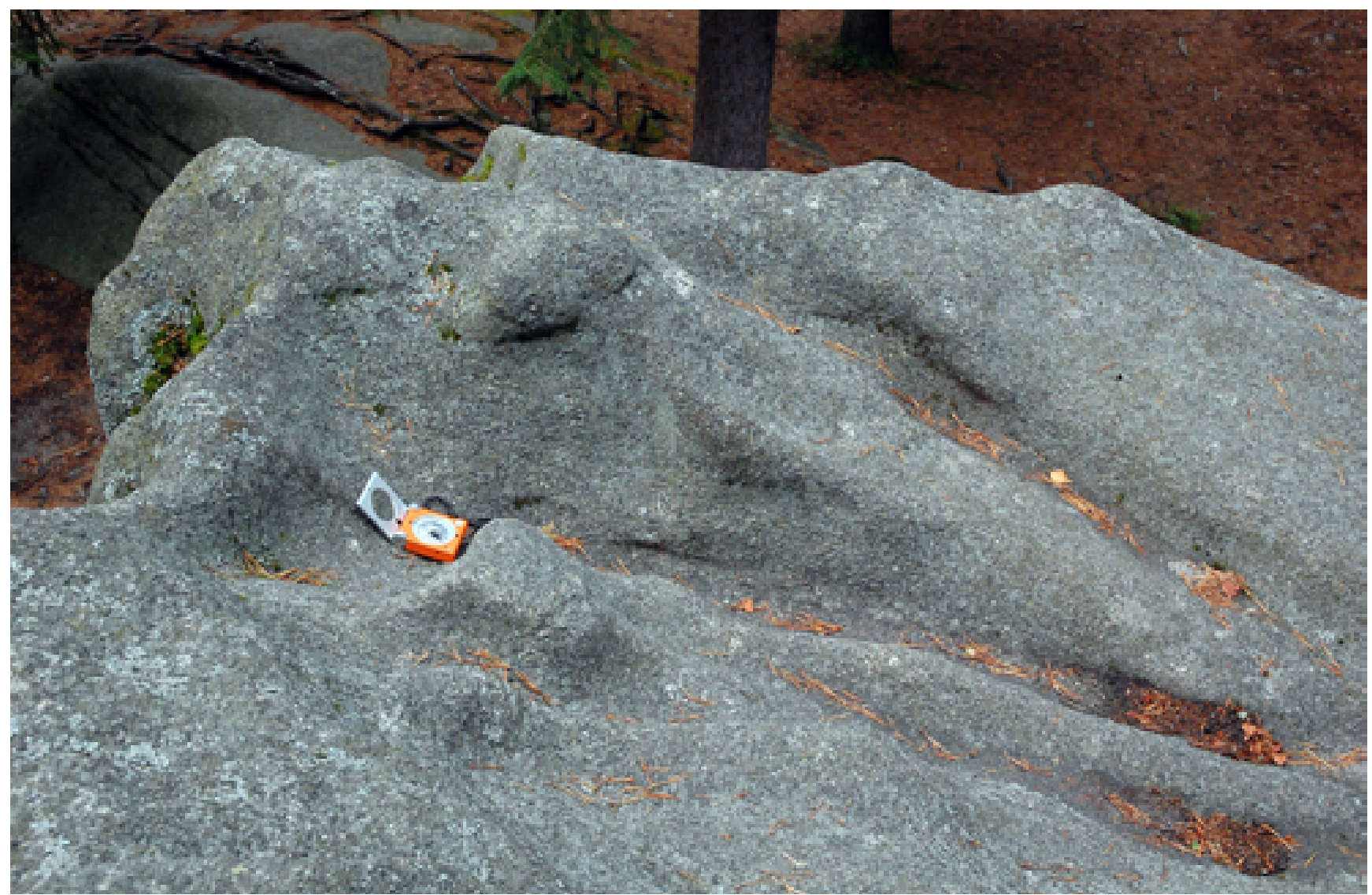

Fig. 9. Dendritic pattern of rills on the upper surface of Hängender Stein, photo P. Migoń • Dendrytyczny układ rynienek na górnej powierzchni Hängender Stein, fot. P. Migoń

Geyersteine consist of three 'mushroom' rocks whose caps once formed a continuous massive slab more than $2.5 \mathrm{~m}$ thick (Fig. 10). Granite below is densely parted by horizontal joints, whilst the upper slab is divided into separate residuals along SSW-NNE vertical joints. The upper edges of all boulders building the form are rounded and their surfaces are diversified by karren covered by mosses. Elevation difference between the top of the tor and the valley bottom is c. $9 \mathrm{~m}$. The valley floor, more than $20 \mathrm{~m}$ wide, is made of densely packed boulders, most probably exposed through preferential fluvial erosion of loose regolith. The tor group of Geyersteine has been described as a residual landform resulting from longterm etchplanation processes (Chábera, Huber, 1995).

Geyersteine are of local cultural significance. On one of the boulders, at the foot of the tor, a stone plaque to commemorate Franz Geyer, a local Waldviertel composer, has been erected. The site can be easily reached from two forest roads accessible to cars, and the distance to the tor is identical (250 m, 5 minutes). There are no tourist facilities near the Geyersteine, with the exception of the wooden bridge leading to the outcrop. The rock formation is well exposed despite its location in a rather dense forest.

Gugelhupfstein. Gugelhupfstein (or Wetterstein) is a large rock outcrop built from Eisgarner Granite, located c. $120 \mathrm{~m}$ to the west from the road connecting the towns of Heidenreichstein and Eisgarn, approximately halfway the distance between them. Outcrop altitude is about $570 \mathrm{~m}$ a.s.l. It is not a classic upstanding tor, but rather a rocky section of the steep side of Räubersgraben valley that rises above its flat floor. The rock wall of Gugelhupfstein is about $55 \mathrm{~m}$ long and follows three directions of vertical joints in granite (N72E, N305W, $\mathrm{N}-\mathrm{S}$ ), which account for its broken course in ground plan. Maximum height is $6 \mathrm{~m}$ in the northern part. Here, a $3 \mathrm{~m}$ high pedestal rock rises above the upper rock platform, with a shape resembling an anvil. Its highest part is dissected by densely spaced karren up to $3 \mathrm{~m}$ long, $10-50 \mathrm{~cm}$ wide and up to $28 \mathrm{~cm}$ deep (Fig. 11). Alternating karren and intervening ribs give distinctive appearance to the outcrop, although they are largely overgrown by mosses. Next to the karren, on the west-facing side, a large flared slope, c. $1.5 \mathrm{~m}$ deep, is present at the base of the pedestal rock. The main rock wall is densely fractured and broken into large blocky compartments in the outer parts. The biggest of them forms an overhang which is $2.2 \mathrm{~m}$ high, $5.5 \mathrm{~m}$ long and $1.8 \mathrm{~m}$ deep. Gravitational displacement of one such block located at the rock wall base caused the origin of a narrow open fissure through the rock spur, $1.5 \mathrm{~m}$ high and 20-30 $\mathrm{cm}$ wide. Approximately in the middle of the rock wall, a few metres in front of it, a large triangular granite monolith lies, $3.6 \mathrm{~m}$ high and $5 \mathrm{~m}$ long. Orientation of its sides is consistent with the principal joint directions in the rock face, suggesting that the monolith is a residual from selective weathering of non-uniformly jointed granite.

Gugelhupfstein is located in a spruce forest, away from marked trails. A small plaque next to the pedestal indicating its status as a protected nature monument is the only sign of management. 


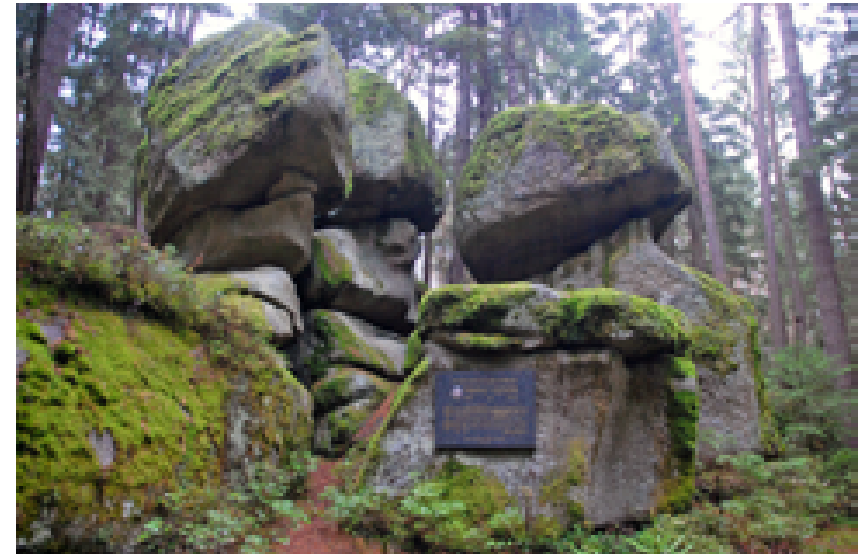

Fig. 10. Rock formations of Geyersteine, photo P. Migoń • Formacje skalne Geyersteine, fot. P. Migoń

Nevertheless, the outcrop has been described in scientific publications and is considered as one of the finest examples of granite karren and flared slopes in the region (Huber, Chábera, 1993, 1994; Huber, 1999).

Hutstein. Hutstein is a singular tor located to the east from the village of Haugschlag, close (less than $1 \mathrm{~km}$ ) to the Austrian-Czech boundary, on the valley side of the Raissbach valley. The height of Hutstein is $5 \mathrm{~m}$. The tor itself is another example of a 'mushroom' rock and consists of two parts (Fig. 12). The upper one, forming the hat, is dissected

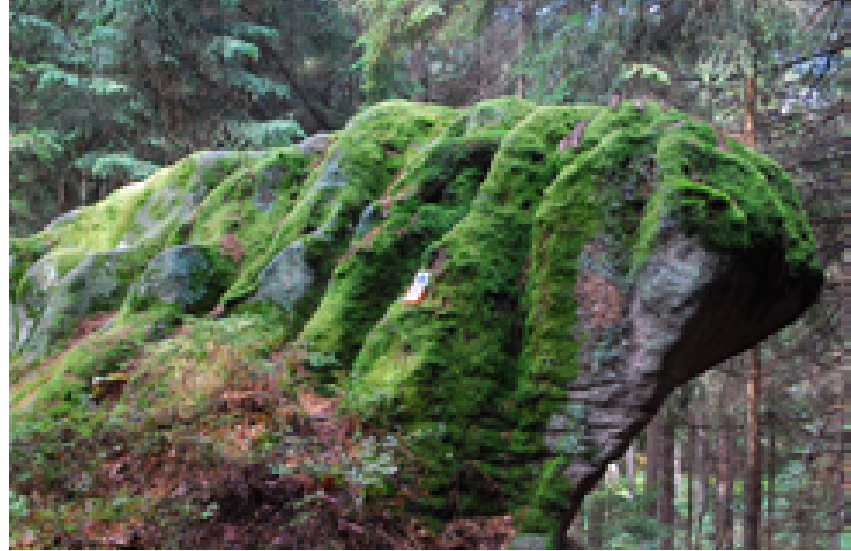

Fig. 11. Moss-overgrown karren of Gugelhupfstein, photo P. Migoń - Pokryte mchem żłobki na skałce Gugelhupfstein, fot. P. Migoń

by numerous karren which in conjunction with parallel ribs create distinct surface micromorphology. The deepest karren are on the east side of Hutstein, with some continuing on the surface of the lower part of the form - the pedestal, but these are poorly developed. Minor weathering forms of Hutstein, not yet overgrown (as in the case of Gugelhupfstein), are considered among the best example of granite karren in the region (Huber, 1999). The tor is hidden in the forest, but access is signposted. There is a small plaque next to Hutstein indicating its name.

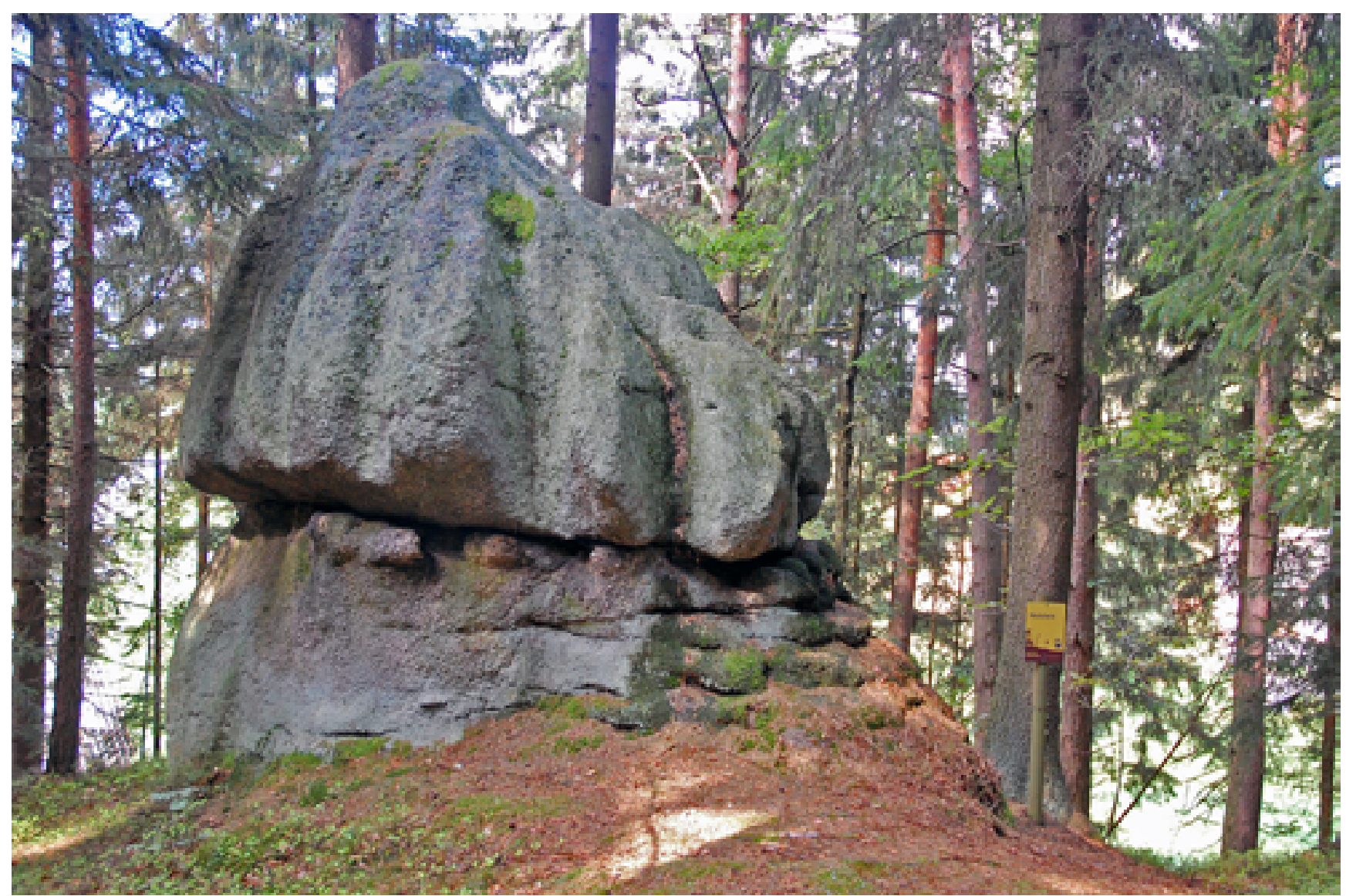

Fig. 12. Karren on Hutstein, photo P. Migoń • Żłobki na skałce Hutstein, fot. P. Migoń 
In addition, an area immediately to the east of Hutstein is of geotourist interest because of an abundance of granite boulders and their good visibility in open agricultural terrain (Fig. 13).

Some of these monolithic boulders attain length of $8 \mathrm{~m}$. They are well rounded and host flared slopes which provide good evidence that boulders formed in the subsurface and have been excavated from weathering mantles through regolith removal.
There are three marked trails in the vicinity of tors, with signposted directions to the cliffs. However, no other tourist infrastructure exists at the site, nor is an information panel present. Although the cliffs are in forested terrain, they are reasonably well exposed. In regional literature they have been described as examples of frost-riven cliffs, i.e. denudational landforms causally related to the Pleistocene periglacial environment (Chábera, Huber, 1999).

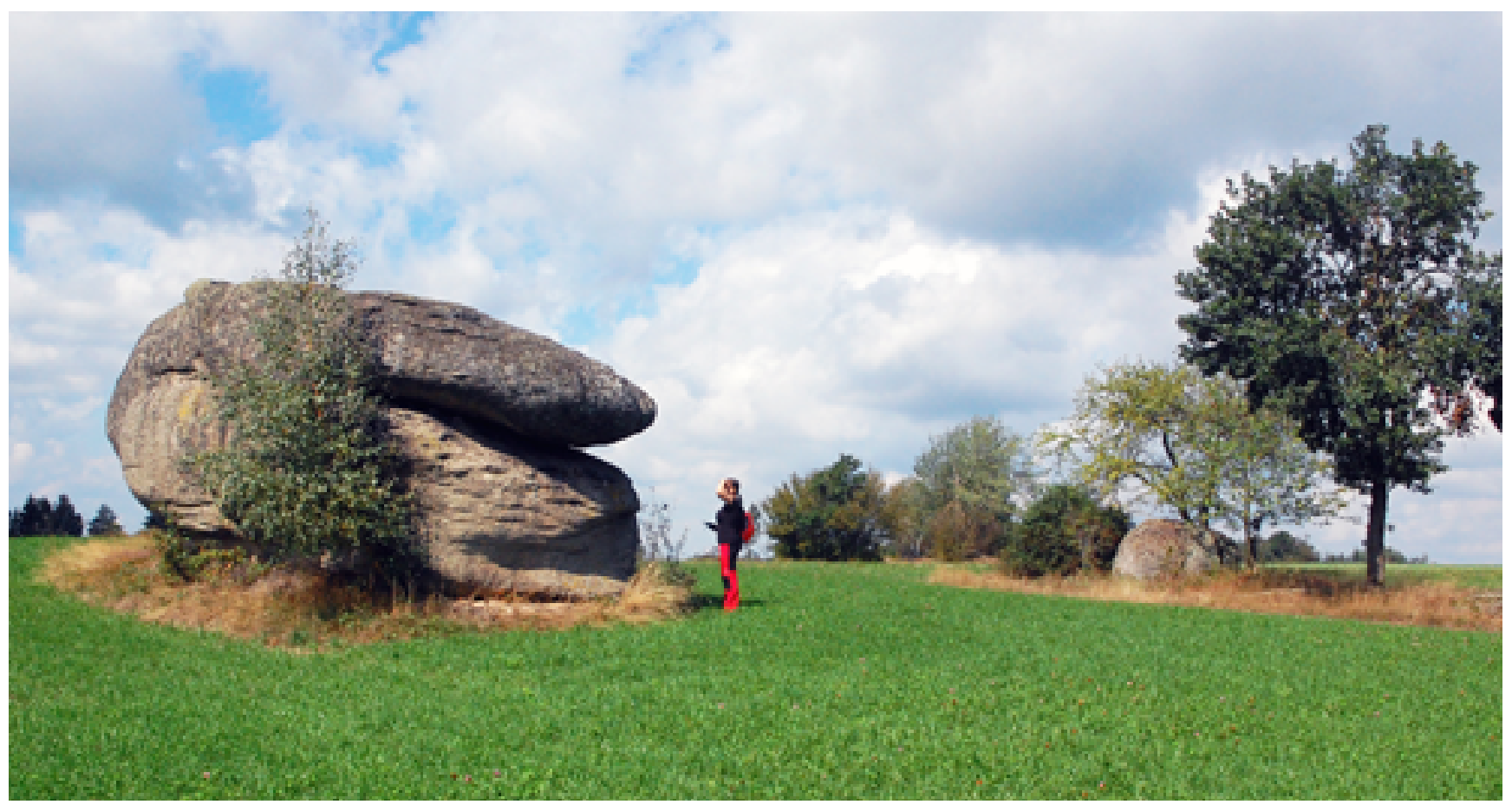

Fig. 13. Large granite boulders and exposed rock platforms in open terrain east of Haugschlag, photo P. Migoń - Wielkie bloki granitowe i platformy skalne na otwartej przestrzeni na wschód od Haugschlag, fot. P. Migoń

\section{Tors near Kautzen (NE Waldviertel)}

In the vicinity of the village of Kautzen, close to the Czech border, the terrain rises to higher elevations, with hilltops exceeding $650 \mathrm{~m}$ a.s.1. Two of them - Hoher Stein $(666 \mathrm{~m})$ and Pyramide $(663 \mathrm{~m})$, host interesting rock formations.

Hoher Stein. Under this name, two adjacent tors below the summit are considered. Their location is to the north from the village of Illmau, about $750 \mathrm{~m}$ southward from the Czech-Austrian border. Both are north-facing edge tors and constitute a sharp break of slope below the flattened summit surface. Bedrock is Eisgarner Granite. Two rock cliff sections are approximately $30 \mathrm{~m}$ away from each other and both follow the same WNWESE direction. The eastern cliff (Fig. 14) is $32 \mathrm{~m}$ long and up to $8 \mathrm{~m}$ high, the western one is $13 \mathrm{~m}$ and $7 \mathrm{~m}$, respectively. Both are built of a rock typified by distinct sub-horizontal partings spaced by about $1 \mathrm{~m}$, and are further dissected by vertical fractures, perpendicular or oblique to the general direction of the cliffs.

At the intersection with one such fractured zone a triangular hollow $5 \mathrm{~m}$ high and $6.5 \mathrm{~m}$ deep has developed in the eastern cliff. Rock cliffs disintegrate due to block fall along primary joints and secondary, tensional fractures parallel to the cliff face. Chaotic blocky talus mantles the surface below the cliffs and continues downslope.
Teufelsstein. An elongated crest of Pyramide is crowned by a discontinuous line of granite outcrops up to $4 \mathrm{~m}$ high. Their shapes are irregular, following rather irregular joint patterns, and tors grade into clusters of large (2-4 m) massive boulder. Similar boulders may be found within the upper slopes. One particularly impressive cluster of massive rock compartments, located to the north-west from the summit, received its own name - Teufelsstein.

Teufelsstein consists of a few large, superimposed blocks emerging in situ from the ground (Fig. 15). The tor is $20 \mathrm{~m}$ long, $11.5 \mathrm{~m}$ wide and $4 \mathrm{~m}$ high. A distinct subhorizontal parting divides the tor into an upper slab (2.5 m thick) and a lower slab (1.5 $\mathrm{m}$ thick). Individual blocks are characterized by elongated and cuboid shapes. The upper block is completely exposed and narrows towards the base, which gives the rock formation an anvil-like shape. The tor is dissected by one horizontal and several vertical joints, which are generally perpendicular to each other. The entire upper surface of the Teufelsstein is overgrown by mosses. Around the tor further singular blocks and boulders, partially exposed, are visible. Their form is typically spherical.

The site is located in the forest, $1 \mathrm{~km}$ to the north from the Radschin - Illmau road. The easiest access to the tor is from Radschin village, by a marked trail. 


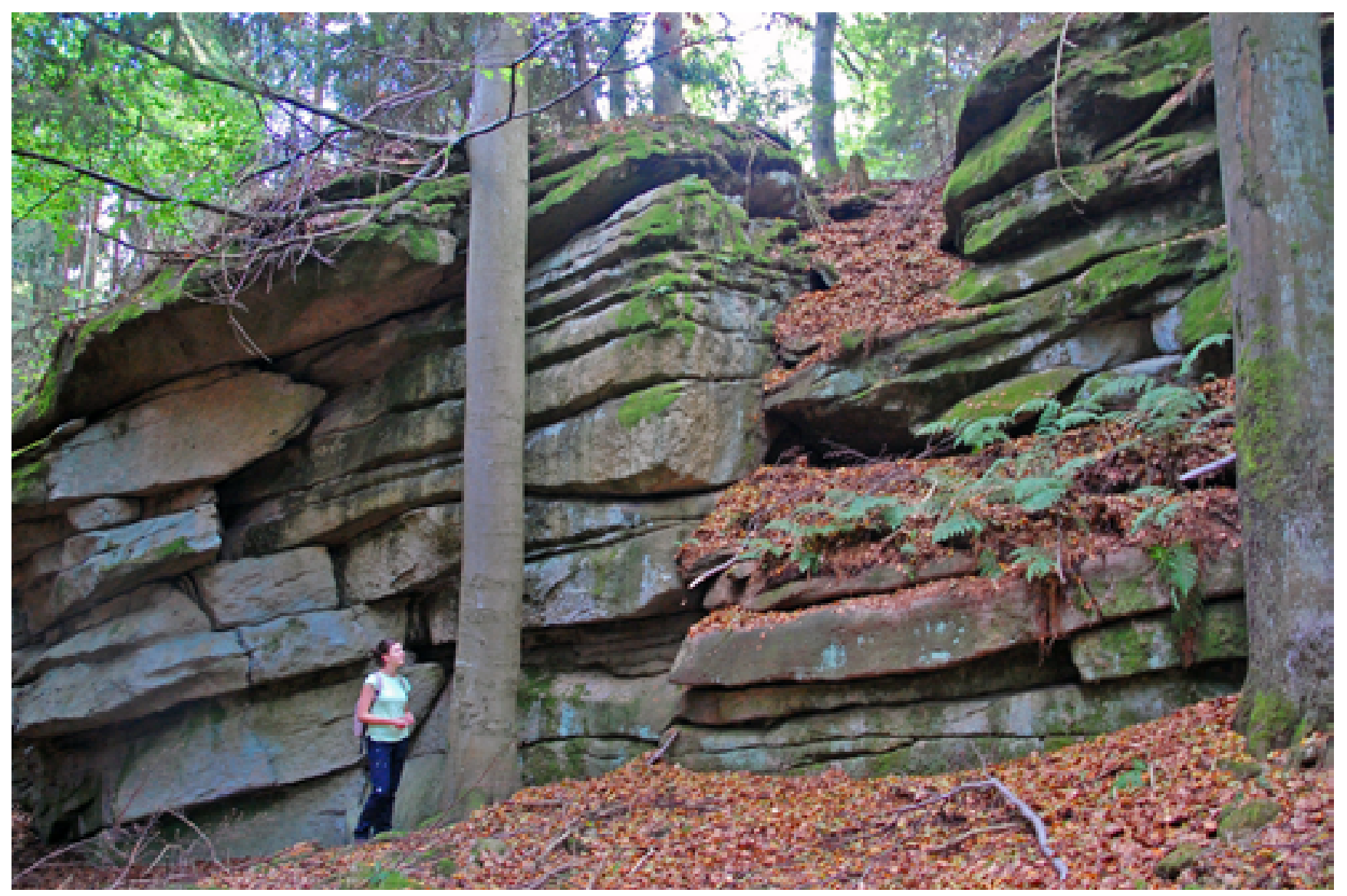

Fig. 14. Rock cliff below the summit surface of Hoher Stein, photo P. Migoń • Klif skalny poniżej powierzchni szczytowej Hoher Stein, fot. P. Migoń

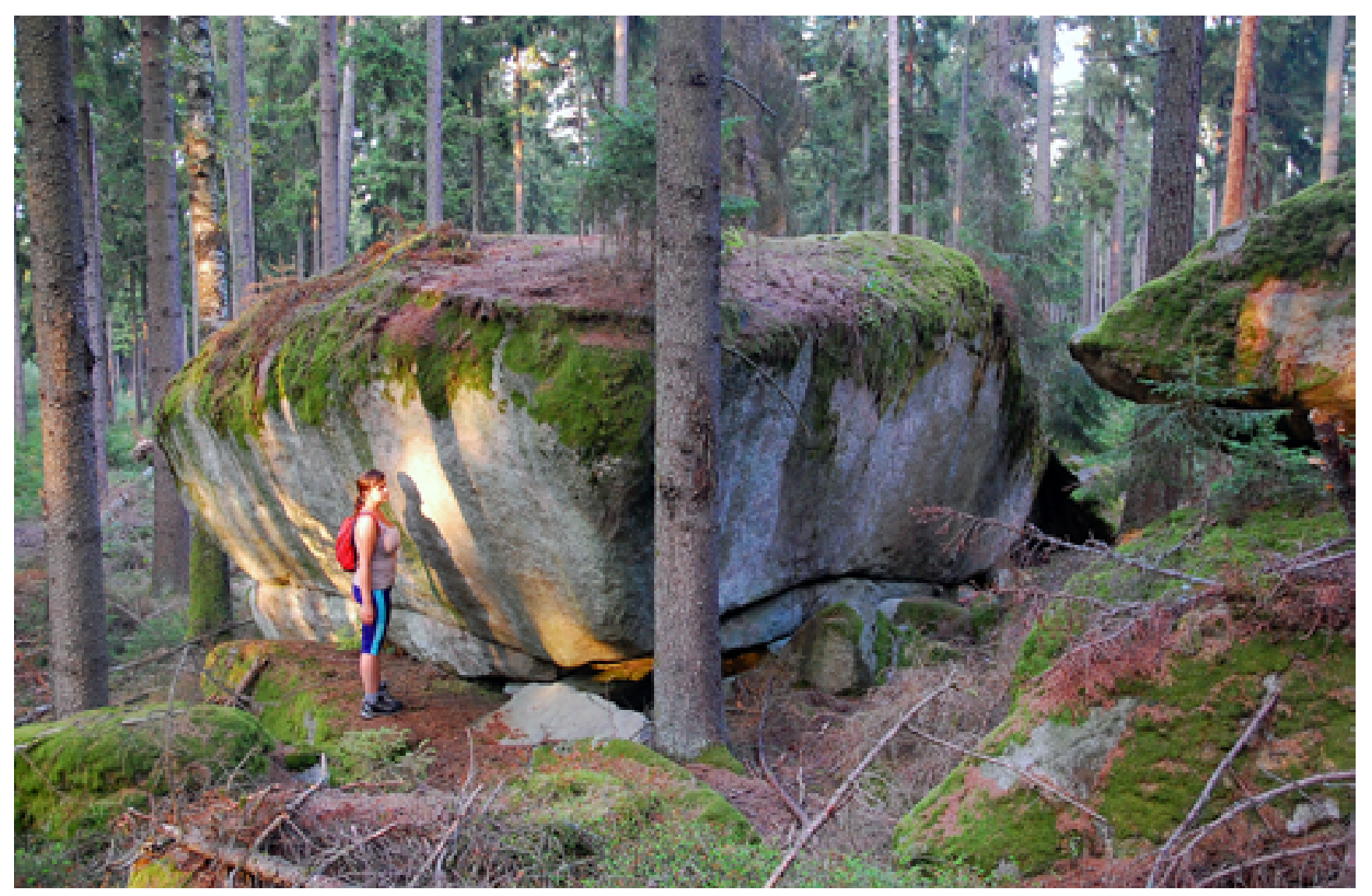

Fig. 15. Teufelsstein is a huge granite monolith, photo P. Migoń • Teufelsstein to wielki monolit granitowy, fot. P. Migoń 
Teufelsstein is slightly overgrown and in some places the rock formation is covered by old toppled trees, but the main geomorphic features are well exposed. No tourist infrastructure is present, except the simple plaque with the name of the tor.

\section{Tors in Gratzener Bergland}

Nebelstein. The summit part of Nebelstein, located in the north-eastern part of the Gratzener Bergland, approximately $9 \mathrm{~km}$ from the town of Weitra in the westerly direction and $4 \mathrm{~km}$ from the Czech-Austrian border, is occupied by several tors separated by irregular blocky talus. One of them constitutes the most elevated spot in the area (1017 $\mathrm{m}$ a.s.1.) and is divided into two towers separated by a cleft that follows one of vertical joints. Horizontal joints perpendicular to them, spaced by $0.5-1 \mathrm{~m}$, give rise to pseudobedding. The height of the summit tor reaches $6 \mathrm{~m}$. Apart from the summit tors, further outcrops in the form of rock cliffs of variable height interrupt otherwise smooth slopes below (Fig. 16). Their angular outlines and cuboid shapes are controlled by prominent vertical joints, which also dictate the pattern of rock mass breakdown. Consequently, a talus of angular blocks mantles the slope beneath the cliffs. Rock formations of Nebelstein are built from Weinsberger Granite.

Nebelstein is situated close to the road connecting mountain villages of Harbach and Harmschlag. A marked trail leads from the parking to the summit, which may be reached in approximately 15 minutes. Close to the top and attached to the tors, there is a mountain lodge offering accommodation and food. A few minutes away from the shelter, on the upper surface of the summit rock tower, a viewing platform with wide vistas over the countryside has been built.

Mandlstein. The summit of Mandlstein is located $2.5 \mathrm{~km}$ to the north from Harbach village and about $250 \mathrm{~m}$ from the Austrian-Czech border. It is crowned by a large castellated tor that extends in north-south direction. The entire rock formation is $95 \mathrm{~m}$ long, up to $15 \mathrm{~m}$ wide and up to $17 \mathrm{~m}$ high, with vertical walls below the top platform. The tor is dissected by sub-horizontal joints whose inclination is broadly conformable with topography, i.e. they are flat-lying along the crest and sloping away from the crest. Thus, pseudobedding is evident and gives Mandlstein a characteristic, platy appearance (Fig. 17). In addition, the entire group is dissected by vertical joints. Some of them have been widened, resulting in the subdivision of the rocky form into three parts and separation of high pulpit rocks in the NW side of tors. Long-term degradation is responsible for the origin of widespread blocky talus around the tor. The shape and position of talus blocks suggest that both sliding and toppling have been involved. Chábera and Huber (1999) link angular shapes of boulders with frost weathering and consider Mandlstein as a landform indicative of periglacial environment. The evidence of surface weathering includes rounded edges of joint-bound compartments associated with woolsack weathering, weathering pits on the top platform, and karren (Chábera, Huber, 1999). A rare feature is a natural rock tunnel, $1.5 \mathrm{~m}$ high, on the western side of the tor, develop through selective weathering acting along a vertical fracture (Fig. 18).

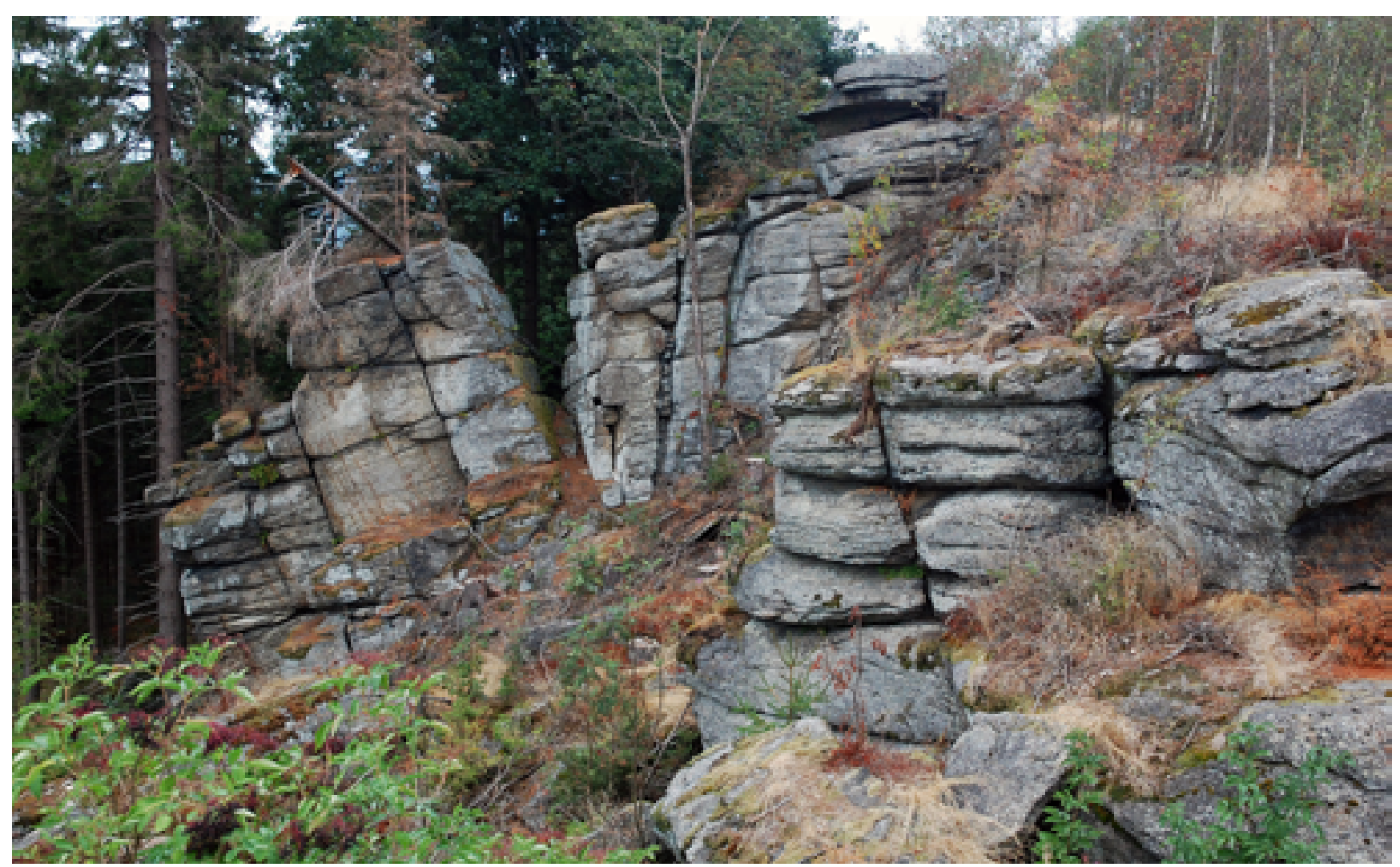

Fig. 16. Rock crags at Nebelstein. Note their angular outlines and the evidence of gravitational displacements due to slow joint opening, photo P. Migoń - Urwiska skalne pod szczytem Nebelstein. Uwagę zwracają ich kanciaste zarysy oraz ślady przemieszczeń grawitacyjnych związanych z powolnym otwieraniem się spękań, fot. P. Migoń 


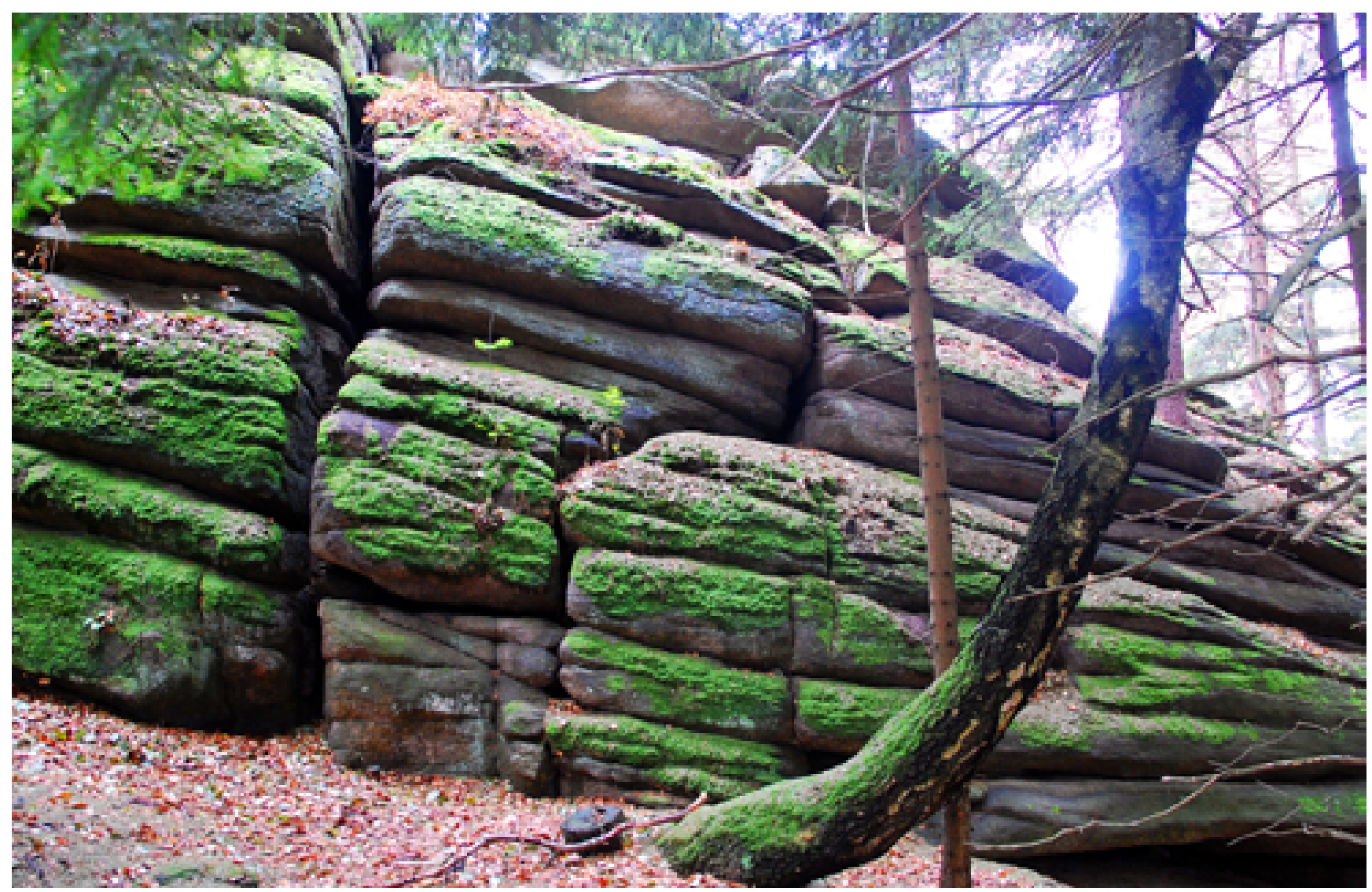

Fig. 17. Pseudobedding at Mandlstein, photo P. Migoń - Pseudowarstwowanie na skałce Mandlstein, fot. P. Migoń

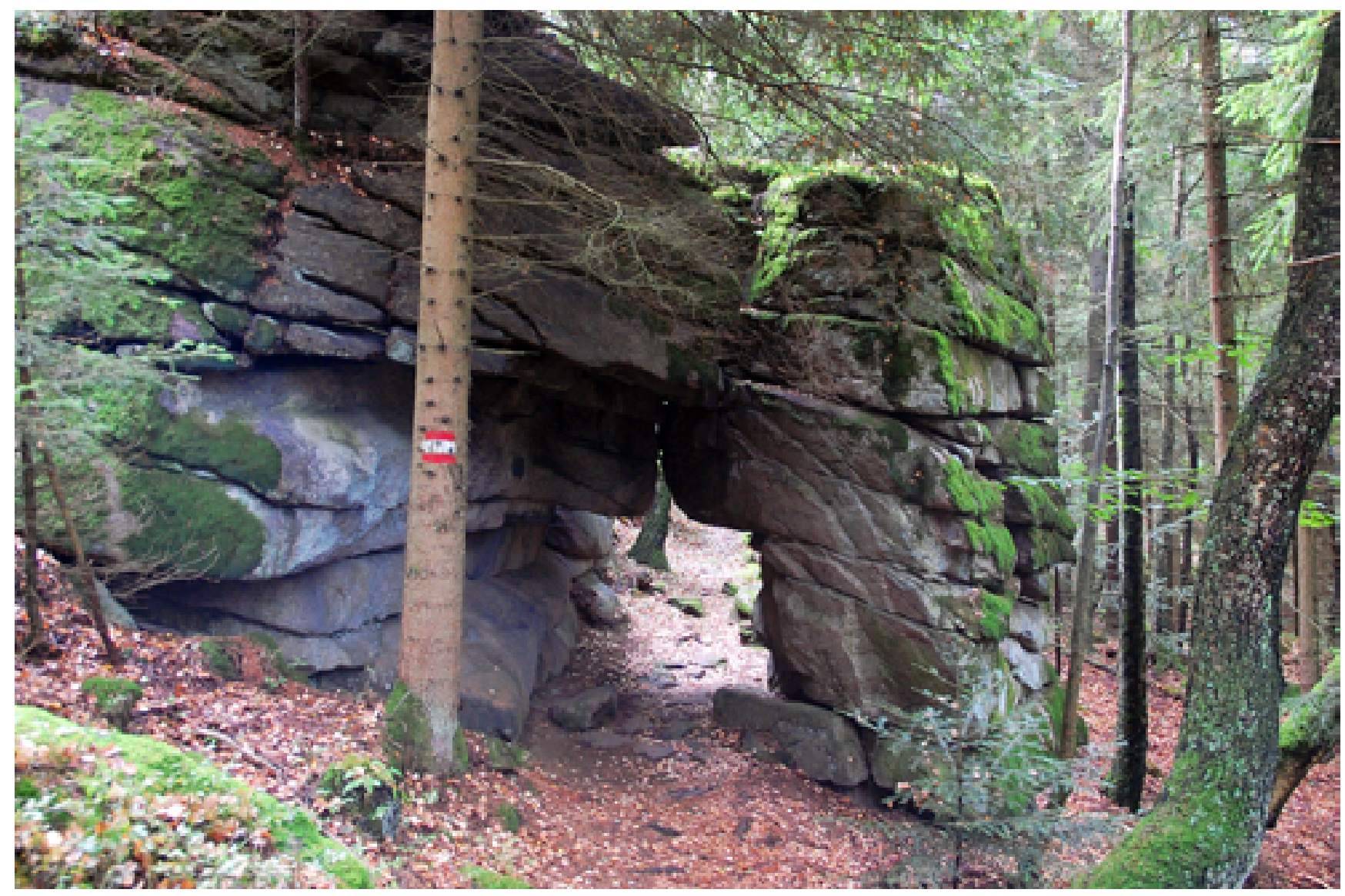

Fig. 18. Natural rock tunnel at Mandlstein, photo P. Migoń • Naturalny tunel skalny na skałce Mandlstein, fot. P. Migoń 
Access to Mandlstein is technically easy. There are two marked trails leading to the tors from a parking by the road connecting Harbach and Heinrichs bei Weitra, where information panels focused on geology and geomorphology of the area have been erected. On the top of the tor a viewing platform has been built, from which a view towards north-west extends. Mandlstein is a stop on the Via Verde trail which is one of the tourist products of Waldviertel region. At the foot of the tor a small chapel has been built, mainly to memorize population displacements after World War II.

Dreilöcherstein (Schalenwunder). This otherwise small and inconspicuous outcrop, located at the periphery of the village of Heinrich bei Weitra, approximately $200 \mathrm{~m}$ to the ENE from the cemetery, is remarkable due to the presence of three unusual weathering pits. Their occurrence on a vertical surface indicates $90^{\circ}$ rotation of the host granite block during degradation of the bouldery tor. The block itself is $3.1 \mathrm{~m}$ long and $2.3 \mathrm{~m}$ high, whilst the pits reach $0.60,0.53,0.50 \mathrm{~m}$ in diameter and $0.26,0.40$ and $0.26 \mathrm{~m}$ deep respectively (Fig. 19). One more, underdeveloped hollow is adjacent to the regular pits. Approximately $23 \mathrm{~m}$ to the west from Dreilöcherstein another granite outcrop with two large weathering pits on its flat upper surface is present. The bigger one, water-filled, is $1.4 \mathrm{~m}$ across and $0.5 \mathrm{~m}$ deep. Access to the site is provided by a local marked trail around the village, but the tor itself is not specifically signposted. A simple panel tells basic information about the locality.

\section{Tourist infrastructure}

Nearly all tors described in this paper are located next to marked trails, with the exception of Gugelhupfstein and Geyersteine. Access to both these sites is, however, easy due to the presence of forest paths, although no signposting indicating the way to them exists. Best accessible is the protected terrain of Blockheide, characterized by particularly high density of marked paths which allow to reach all interesting rock formations in the area. Blockheide has long been a favourite outdoor recreation ground for the town of Gmünd and numerous tors and boulders add to its appeal. Likewise, forest grounds to the east of Heidenreichstein, where the Hängender Stein tor is located, have been developed into a recreation area. The distance from nearest roads varies but is generally small and walks no longer than 20 minutes are required to reach the tors. In several cases only a few minutes walks are necessary (e.g. Dreilöcherstein, Wackelstein near Amaliendorf, Gugelhupfstein). The only exception among the sites considered here are tors in the vicinity of Kautzen which can be reached in about 45 minutes. However, designated parking is not everywhere present. Whilst most tors are in natural state, two most elevated mountain-top locations, i.e. Nebelstein and Mandlstein, have been specially developed for tourism. Access to their upper parts required trail engineering and viewing platforms with handrails have been erected.

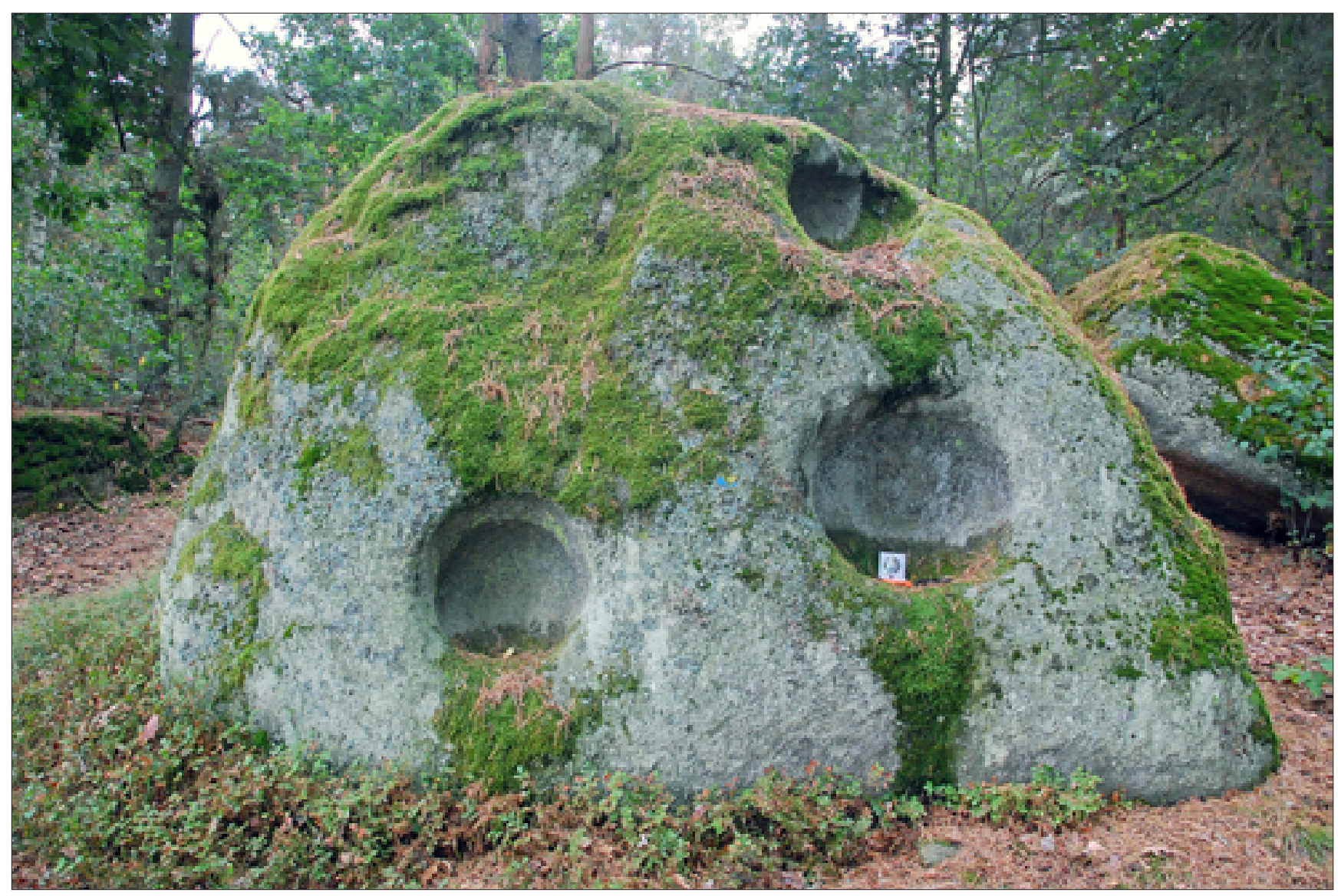

Fig. 19. Weathering pits on a rotated granite block of Dreilöcherstein, photo P. Migoń • Kociołki wietrzeniowe na obróconym bloku granitowym Dreilöcherstein, fot. P. Migoń 
Trails leading to the tors are in good technical condition, although marking is not always clear (especially near Kautzen) and the presence of a site of interest is occasionally not indicated (Dreilöcherstein).

Whilst access to all tors presented in this paper is technically easy, on-site information and interpretation is very scarce. At the majority of sites it is non-existent or limited to a simple plaque indicating the name and protected status. Some tors and boulder clusters have been incorporated into local heritage trails (Dreilöcherstein near Heinrichs, Wackelstein near Amaliendorf, Hutstein), but no specific information related to either tor morphology or wider geological context of the region has been provided. The only two localities where geoscientific interpretation is offered via information panels, are Hängender Stein and Mandlstein. However, although in the former case the board is at the site itself, at the latter the panel has been erected at the parking lot, $0.5 \mathrm{~km}$ away from the tor itself. Furthermore, the panel at Hängender Stein is the only one among the sites that clearly explains the origin of the tors and includes diagrams (Fig. 20), although it requires renovation.

Tourist infrastructure is best developed at Blockheide and includes an information centre, an extensive network of marked trails, two thematic trails, and an open-air geological exhibition. Whilst one of the trails is focused on biology, and specifically on biotope diversity and food chains, the other one, called GRANITkulTOUR, explores the use of granite and methods of stoneworking in the past and at present. Occasionally, historical information is provided, e.g. about the

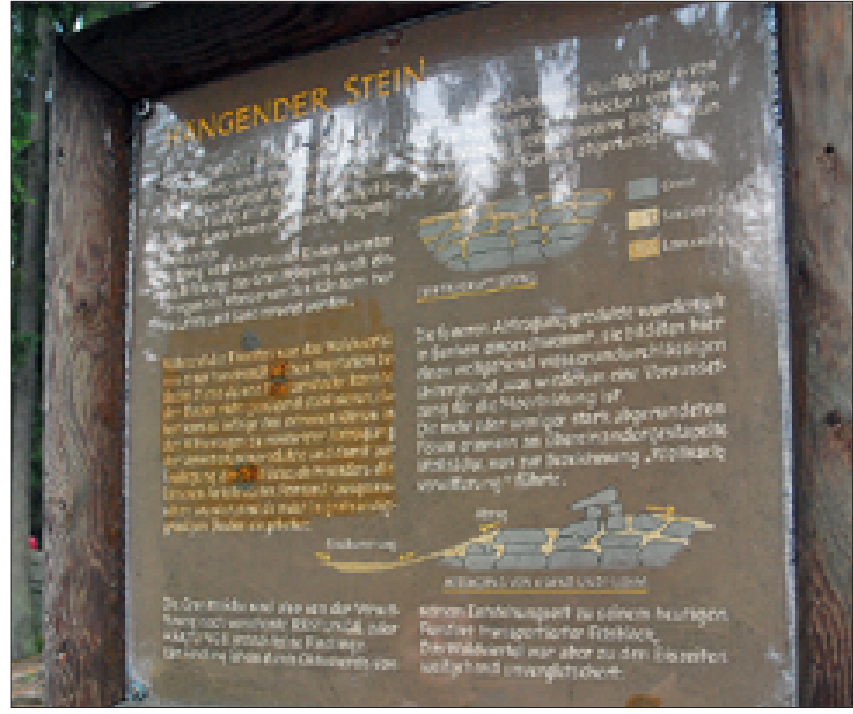

Fig. 20. Interpretation panel next to Hängender Stein to explain the two-phase origin of tors, photo P. Migoń - Tablica objaśniająca dwuetapowe powstawanie skałek granitowych przy skałce Hängender Stein, fot. P. Migoń

so-called Lutherische Kirche - once the largest granite monolith in the area, completely excavated for building stones. The geological exhibition, in turn, shows more than 30 rock specimens assembled in five genetic groups, with granites as one of them (Fig. 21).

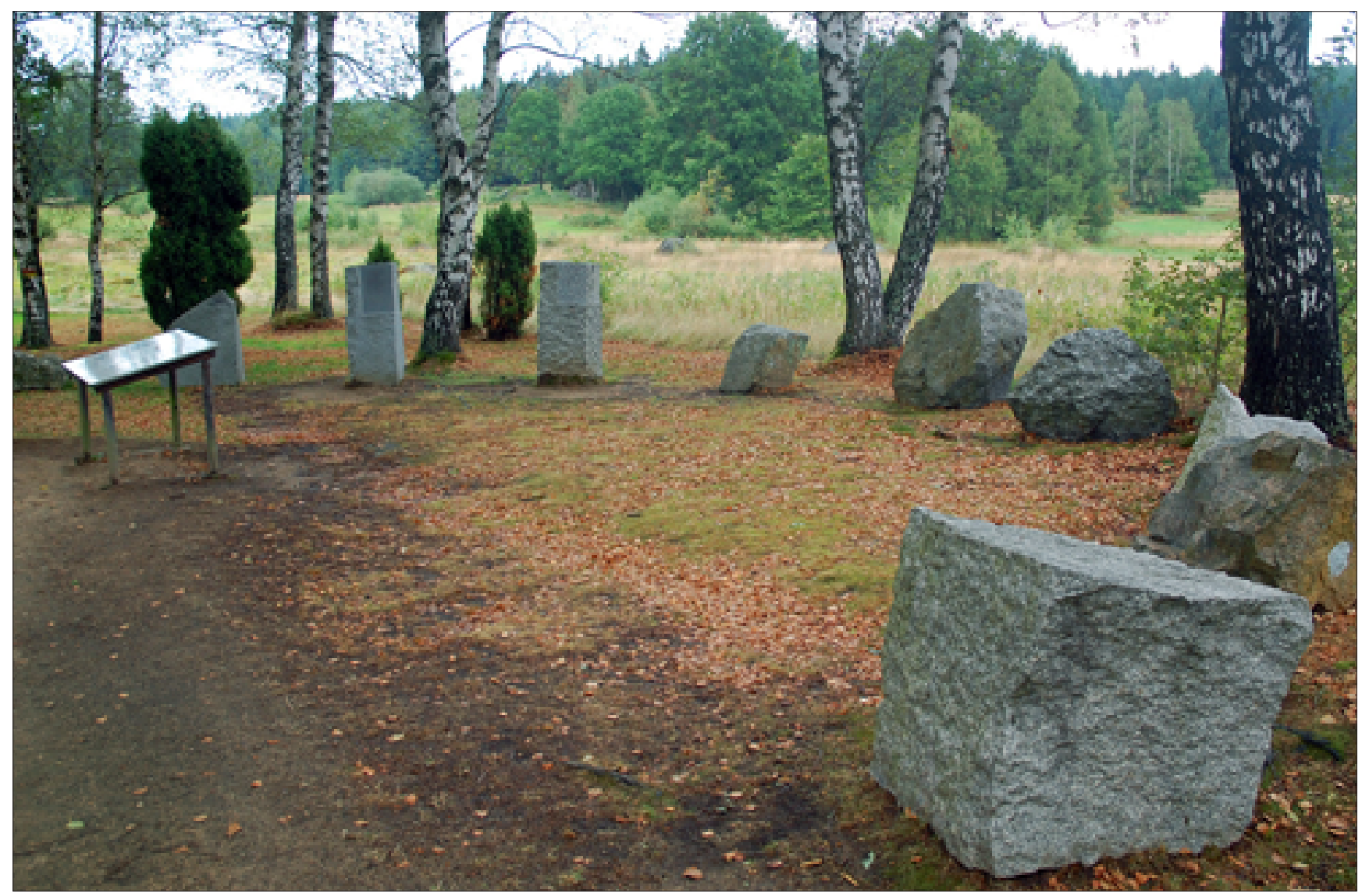

Fig. 21. Examples of granite rocks at the open-air geological exhibition in Blockheide, photo P. Migoń • Przykłady skał granitowych pokazane na ekspozycji geologicznej na wolnym powietrzu w Blockheide, fot. P. Migoń 
However, no interpretation of landform diversity and the origin of rock formations is available.

Rather surprisingly, some granite tors, despite their outstanding scientific and scenic value, are hardly promoted as regional assets, not marked on available maps, and not signposted. An example of such 'forgotten' tors is Gugelhupfstein - an excellent example of granite karren, and yet hidden in the forest and lacking information that could be helpful to find the site. Only papers published in poorly available publications (Huber, Chábera, 1993, 1994) give a clue how to access the tor. In fact, there are many further examples of interesting tors and boulders in the Waldviertel area which are not developed as geotourist destinations.
One of them is Steingarten (Stone Garden) located near Schandachen, northwest from the town of Litschau. The locality abounds in tors and boulders, some with well-developed minor features such as karren, weathering pits, and flared slopes. However, they are not mentioned within the local heritage trail and poorly visible because of tree growth. Graselstein, located north from Litschau, is another example of rock formation reported in scientific literature and marked on maps, but without any signs of development despite proximity to a marked trail. Large basal overhangs, covered clefts and weathering pits contribute to the value of the tor which therefore deserves more attention.

Tab. 1. Diversity of tor morphology and microrelief in NW Waldviertel • Zróżnicowanie rzeźby skałkowej i mikroform w północno-zachodniej części Waldviertel
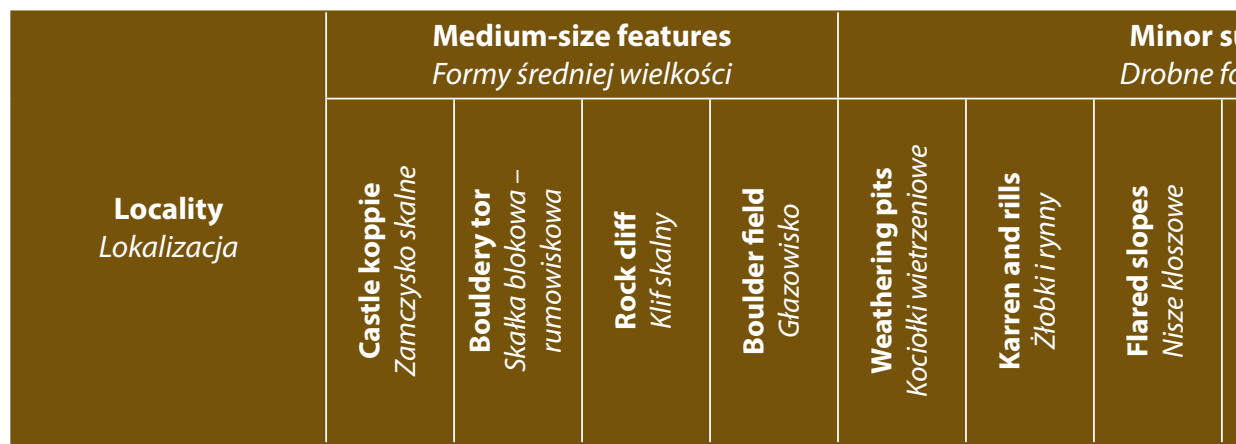

Minor surface features Drobne formy powierzchni

Blockheide Natur Park

Park Przyrodniczy Blockheide

\begin{tabular}{|c|c|c|c|c|c|c|c|c|c|c|c|}
\hline Koboldsteine & & + & & & & & + & & & + \\
\hline Teufelsbett & & + & & & & & & & & \\
\hline Christophorusstein & + & & & & ++ & & & + & & + \\
\hline Pilzstein & & + & & & & & + & & + & + & + \\
\hline Wackelsteine * & & + & & & & & & & & ++ & + \\
\hline
\end{tabular}

Other localities

Pozostałe lokalizacje

\begin{tabular}{|c|c|c|c|c|c|c|c|c|c|c|}
\hline Mandlstein & + & & & & + & + & & ++ & & ++ \\
\hline Nebelstein & + & & + & & & & & + & & \\
\hline Dreilöcherstein & & + & & & + & & & & & \\
\hline $\begin{array}{l}\text { Wackelstein ** (Ama- } \\
\text { liendorf) }\end{array}$ & & + & & + & ++ & & ++ & & + & \\
\hline Hängender Stein & + & & & & + & + & & & & \\
\hline Gugelhupfstein & & & + & & & ++ & + & + & & \\
\hline Hutstein $* * *$ & & + & & + & & ++ & + & + & + & \\
\hline Geyersteine & & + & & & & + & & & + & + \\
\hline $\begin{array}{c}\text { Pyramiden - Teufel- } \\
\text { stein }\end{array}$ & & & & + & & & & & & \\
\hline Hoher Stein & & & + & & & & & ++ & & \\
\hline
\end{tabular}

* four balanced rocks occur in Blockheide; ** includes adjacent boulders and platforms, with their diverse microrelief; *** includes solitary boulders present in the vicinity. Explanation for 'minor surface features': (++) outstanding example; $(+)$ present • * na obszarze Blockheide znajdują się cztery skatki chybotki; ** obejmuje także sąsiednie bloki i platformy skalne, z ich zróżnicowana rzébą; *** obejmuje pojedyncze bloki w sąsiedztwie. Objaśnienie dotyczace ,, drobnych form powierzchni": (++) bardzo dobry przyktad; (+) wystepuje 


\section{Thematic trail}

Diversity and good access are necessary ingredients of any thematic geotourist itineraries, whether hiking trails, biking routes, or drives. Whereas walking trails are common proposals, self-driving routes can be good alternatives for visitors with limited time and interest in regional geology/ geomorphology. The abundance of tors in Waldviertel and their proximity to roads accessible to private cars is an opportunity to suggest one-day 'Granite Tors Route' (from now on 'the Route') which would allow to see representative examples of tors of the region. Table 1 summarizes tor diversity in the region and provides background to select localities for the Route.

The Route starts in Gmünd and leads to Blockheide area, which is an excellent introduction to the region in terms of geology and landforms. Although the dense network of trails allows great flexibility in planning the visit, the recommended walking itinerary starts at the viewing tower, to appreciate the rolling landscape typical for granite terrains of Waldviertel, followed by the open-air exhibition of rocks from the region. Subsequent visit to four outcrops: Teufelsbett/Teufelsbrotlaib, Wackelstein, Christophorusstein, and Pilzstein, shows both examples of tors of various types as well as boulder clusters and solitary boulders. Weathering pits - the most characteristic microforms for granite outcrops in Central Europe - can be seen at Christophorusstein. It is envisaged that approximately three hours will be spent in Blockheide area.

The second part of the Route includes the area around Heidenreichstein, which is about $20 \mathrm{~km}$ away from Gmünd (Fig. 1). Numerous tors occur in the surrounding of the town and whilst morphologically they resemble those in Blockheide, they offer striking examples of microforms related to surface and subsurface weathering. Near Amaliendorf one can see fully developed flared slopes and large weathering pits. The next location is Hängender Stein, with a fine set of rills and furrows. Finally, a visit of Gugelhupfstein provides an opportunity to examine the best developed karren in granites. In addition, this locality represents a type of tor not seen before $-\mathrm{a}$ joint-controlled rock cliff.

Thus, the Route, as proposed here, consists of four stops, is $40 \mathrm{~km}$ long one way, includes one longer and three short walks (c. 30-40 minutes each), and may be attempted in one day. However, to become a geotourist itinerary, explanation and interpretation have to be provided, whether in the field or as web-based resources. So far, interpretative materials are very scarce.

\section{Conclusions}

Central Europe, and the Bohemian Massif in particular, have long been known for their granite landscapes. One of early syntheses of granite geomorphology was heavily based on examples from this region (Wilhelmy, 1958), and significant contributions to the understanding of tors and boulders have been made by Czech geomorphologists (Czudek et al., 1964; Demek, 1964). However, granite tors of Waldviertel remained poorly known and were regarded as local curiosities rather than geosites of wider significance. Nevertheless, the review presented above - if compared with the accumulated knowledge about granite landforms elsewhere in the Bohemian Massif (e.g. Demek, 1964; Votýpka, 1964, 1974, 1979; Jahn, 1974; Migoń, 1996; Štěpančíková, Rowberry, 2008) - leaves little doubt that Waldviertel hosts a highly diverse, and hence representative suite of residual granite landforms for Central European upland basement landscapes. This diversity is evident at both medium (tor types, boulder shapes) and microscale (minor weathering features). Thus, there is clearly scope for comprehensive presentation of granite geoheritage to the public. In addition, access to most tors and boulders is invariably easy and they can be visited with limited effort. Consequently, granite landforms of Waldviertel are well suited to develop geotourism. However, there is general deficit of interpretation, even at Blockheide, with its most extensively developed tourist infrastructure. After additional interpretative facilities are provided, the region may become a premier geotourist destination in the Bohemian Massif.

\section{References (Literatura)}

Campbell S., Gerrard A.J., Green C.P., 1998. Granite landforms and weathering products. In: Campbell S., Hunt C.O., Scourse J.D., Keen D.H. (eds), Quaternary of South-West England. Chapman and Hall, London: 73-90.

Chábera S., Huber K.H., 1995. Pilzfelsen und Wackelsteine in Granitoiden des Südböhmischen Plutons. Sborník Jihočeského muzea v Českých Budějovicích. Přirodní vědy, 35: 5-20.

Chábera S., Huber K.H., 1996. Polygonalstrukturen (polygonal cracking) auf Felsoberflächen aus Eisgarner Granit. Sborník Jihočeského muzea $v$ Českých Budéjovicich. Přrrodni vědy, 36: 5-22.

Chábera S., Huber K.H., 1998. Pseudoschichtung (pseudobedding) in Granitoiden des Südböhmischen Plutons. Sborník Jihočeského muzea v Českých Budějovicích. Př́rodní vědy, 38: 5-17.

Cui Z., Chen Y., Yang X., 2009. Granite landform characteristics, distribution and evolution patterns in Huangshan Mt. Chinese Science Bulletin, 2009: 1-13, doi: 10.1007/s11434-009-0309-x.

Czudek T., Demek J., Marvan P., Panoš V., Raušer J., 1964. Verwitterungsund Abtragungsformen des Granits in der Böhmischen Masse. Petermanns Geographische Mitteilungen, 108: 182-192.
Demek J., 1964. Castle koppies and tors in the Bohemian Highland (Czechoslovakia). Biuletyn Peryglacjalny, 14: 195-216.

Höck V., 1999. Der geologische Bau des Grundgebirges. In: Steininger F.F. (ed.), Erdgeschichte des Waldviertels. Waldviertler Heimatbund, Horn Waidhofen/Thaya: 37-60.

Huber K.H., 1999. Zum Formenschatz der Granitverwitterung und -abtragung im nordwestlichen Waldviertel. In: Steininger F.F. (ed.), Erdgeschichte des Waldviertels. Waldviertler Heimatbund, Horn - Waidhofen/ Thaya: 113-132.

Huber K.H., 2003. Some field observations and remarks on the Gmünd beds of the northwestern Waldviertel region (Lower Austria). Jahrbuch der geologischen Bundesanstalt, 143: 543-566.

Huber K.H., Chábera S., 1993. Nové lokality žlábkových škrapu v žulach centrálního masívu moldanubického plutonu. Sborník Jihočeského muzea v Českých Budějovicích. Přirodní vědy, 33: 5-14.

Huber K.H., Chábera S., 1994. Úpatní výklenky na žulových balvanech moldanubika. Sborník Jihočeského muzea v Českých Budějovicích. Přirodní vědy, 34: 5-16.

Hundert Meisterwerke. Die schönsten Geotope Bayerns. Bayerisches Landesamt für Umwelt, Augsburg 2012.

Jahn A., 1974. Granite tors in the Sudeten Mountains. Institute of British Geographers, Special Publication, 7: 53-61. 
Koller F., 1999. Plutonische Gesteine. In: Steininger F.F. (ed.), Erdgeschichte des Waldviertels. Waldviertler Heimatbund, Horn - Waidhofen/Thaya: 25-36.

Lageat Y., 2013. The "Pink Granite" Coast (Northern Brittany). In: Fort M., André M.-F. (eds), Landscapes and Landforms of France. Springer, Dordrecht: $53-60$.

Linton D.L., 1955. The problem of tors. Geographical Journal, 121:470-487. Migoń P., 1996. Granite landscapes of the Sudetes Mountains - some problems of interpretation: a review. Proceedings of the Geologists' Association, 107: 25-38.

Migoń P., 2007. Sanqingshan - ukryty skarb Chin. Geoturystyka, 2(5): 33-40.

Štěpančíková P., Rowberry M., 2008. Rock landforms that reflect differential relief development in the north-eastern sector of the Rychlebské hory and the adjacent area of Žulovská pahorkatina (SE Sudeten Mts, Czech Republic). Acta Geodynamica et Geomaterialia, 5, 3 (151): 297-321.
Twidale, C.R., 1968. Origin of Wave Rock, Hyden, Western Australia. Transactions of the Royal Society of South Australia, 92: 115-123.

Twidale, C.R., 1982. Granite Landforms. Elsevier, Amsterdam.

Věžník A., 1982. Některé mezo- a mikroformy zvětrávání a odnosu žuly v Novobystřické vrchovině. Sbornik Československé Společnosti Zemépisné, 87: 13-22.

Votýpka J., 1964. Tvary zvětrávání a odnosu žuly v severní částí Novobystřické vrchoviny. Sborník Československé Společnosti Zeměpisné, 69: 243-258.

Votýpka J., 1974. Vznik a vývoj mezoreliéfu a mikroreliéfu Sedmihoří. Acta Universitatis Carolinae, Geographica, 2: 17-34.

Votýpka J., 1979. Geomorfologie granitové oblasti masívu Plechého. Acta Universitatis Carolinae, Geographica, 16(2): 55-83.

Wilhelmy H., 1958. Klimamorphologie des Massengesteine. Westermann, Braunschweig. 